\title{
NONLEGISLATIVE RULEMAKING AND REGULATORY REFORM
}

\author{
MiCHAEL AsIMOW*
}

The adoption of interpretive rules and policy statemens is a vital part of the administrative process. These "nonlegislative" rules clarify the language of statutes and prior rules and give structure to agency discretionary powers. Courts have encountered difficulty in distinguishing legislative from nonlegislative rules because the practical impact of both kinds of rules may be the same. Regulatory reform proposals at both federal and state levels would require agencies to employ notice and comment procedures before adopting many nonlegislative rules. This article contends that such requirements would discourage agencies from adopting nonlegislative rules and thus would dramatically disserve the public interest.

Both the federal Administrative Procedure Act of 1946 (APA) ${ }^{1}$ and the Model State Administrative Procedure Act of $1961^{2}$ require agencies to invite public participation before adopting legislative rules. However, the two statutes prescribe different procedures for adopting nonlegislative rules, ${ }^{3}$ a category that includes interpretive ${ }^{4}$ rules and pohcy stateinents.

Under the federal APA, an agency has discretion to adopt nonlegislative rules without any pre- or post-adoption procedure, ${ }^{5}$ other than a requirement that it publish rules of general applicability in the Federal

* Professor of Law, UCLA Law School. The author gratefully acknowledges the invaluable help of Carl Auerbach, Richard Berg, Arthur Bonfield, Werner Hirsch, Frances Olsen, Bill Ong Hing, and Sallyanne Payton.

1. 5 U.S.C. $\S 553($ b), (c) (1982).

2. Model State Administrative Procedure Act of 1961, Section 3, 14 U.L.A. 387 (1980) [hereinafter cited as 1961 MODEL ACT].

3. Broadly speaking, a "legislative" rule is adopted pursuant to a delegation to an agency by a legislature. See Joseph v. United States Civil Serv. Comm'n, 554 F.2d 1140, 1153 n.24 (D.C. Cir. 1977). A "nonlegislative rule" is one adopted by an agency but not pursuant to delegation of legislative power.

Judicial decisions sometimes use the terms "substantive" or "nonsubstantive" rules whereas this article uses the terms "legislative" or "nonlegislative" rules. The word "substantive" is confusing because it is ordinarily the opposite of "procedural." See 5 U.S.C. $\$ 552(a)(1)(C)$, (D) (nsing the term "substantive rules" in clear opposition to "rules of procedure"). However, none of the rules discussed in this article are procedural. The distinction is between legislative and nonlegislative, not substance and procedure. The APA exenption for procedural rules is not discussed in this article.

4. The APA uses the word "interpretative" whereas this article will use the stylistically preferable "interpretive." Both versions are in common use in statutes, judicial decisions, and scholarly work.

5. 5 U.S.C. $\S 553(b)(A),(d)(2)$. Of course, agencies frequently provide pre-adoption notice and comnient procedures even though not legally required to do so. 
Register after adoption. ${ }^{6}$ The nonlegislative rule exemptions in the federal APA have proved difficult to apply in practice and have been the subject of constant litigation. ${ }^{7}$ In contrast, the 1961 Model State Act requires the same pre-adoption procedure for legislative and nonlegislative rules. ${ }^{8}$

Proposed federal regulatory reform legislation would sharply narrow the exemption provided by existing law. ${ }^{9}$ Meanwhile, the recently approved 1981 Model State Administrative Procedure Act provides only modest exemptions for nonlegislative rules. ${ }^{10}$

This article contends that the costs of niandatory advance public participation in the making of nonlegislative rules outweighs the benefits and that the proposed statutory revisions will not solve the definitional problems of existing law. As a result, this article argues that the state and federal reform proposals shonld be rejected. Instead, this article endorses the proposal, adopted by the Administrative Conference of the United States, that post-adoption participation be provided in nonlegislative rulemaking. ${ }^{11}$

6. 5 U.S.C. $\$ 552(\mathrm{a})(1)(\mathrm{D})$.

7. For other discussions of the nonlegislative rule exemptions, see 1 and $2 \mathrm{~K}$. DAVIS, ADMINistrative Law Treatise $\S \S 6.30-.31,7.4-7.21$ (2d ed. 1978 \& Supp. 1982); Asimow, Public Par. ticipation in the Adoption of Interpretive Rules and Policy Statements, 75 MICH. L. REv. 521 (1977); Bonfeld, Some Tentative Thoughts on Public Participation in the Making of Interpretative Rules and General Statements of Policy under the A.P.A., 23 AD. L. REv. 101 (1971); Koch, Public Procedures for the Promulgation of Interpretative Rules and General Statements of Policy, 64 GEo. L.J. 1047 (1970); Warren, The Notice Requirement in Administrative Rulemaking: An Analysis of Legislative and Interpretive Rules, 29 AD. L. REv. 367 (1977); Note, An Analysis of the General Statement of Policy Exception to Notice and Comment Procedure, 73 GEo. L.J. 1007 (1985); Note, The Interpretive Rule Exemption: A Definitional Approach to Its Application, 15 IND. L. REv. 875 (1982); Note, Administrative Law-The Legislative-Interpretative Distinction: Semantical Feinting with an Exception to Rulemaking Procedures, 54 N.C.L. REV. 421 (1970); Note, A Functional Approach to the Applicability of Section 553 of the Administrative Procedure Act to Agency Statements of Policy, $43 \mathrm{U}$. CHI. L. REv. 430 (1970) [hereinafter cited as Note, A Functional Approach]; Note, Revenue Rulings and the Administrative Procedure Act, 1975 Wis. L. REv. 1135.

8. 1961 MoDEL ACT, supra note 2, at $\S \S 1(7),(3)$.

9. See infra notes 182-204 and accompanying text. Proponents of regulatory reform often have been preoccupied with other matters. See, e.g., Sargentich, The Reform of the American Ad. ministrative Process: The Contemporary Debate, 1984 WIs. L. REv. 385, $438-42$ (discussing competing ideals in regulatory reform); Strauss, Regulatory Reform in a Time of Transition, 15 SUFFOLX U.L.REV. 903, 904 (1981) (discussing hinits on regulatory reform).

10. Model State Administrattve Procedure Act § 2-101, 14 U.L.A. 67 (1984 Supp.) [hereinafter cited as the 1981 ModeL ACT]. See infra notes 132-81 and accompanying text. See generally Bonfeld, An Introduction to the 1981 Model State Administrative Procedure Act, Part 1, 34 AD. L. REv. 1 (1982).

11. See infra notes $205-25$ and accoinpanying text. 


\section{Nonlegislative Rules: Definitions and Functions}

\section{A. Preliminary Definition of Terms.}

The theoretical difference between legislative and nonlegislative rules is clear. A legislative rule is essentially an adninistrative statutean exercise of previously delegated power, new law that completes an incomplete legislative design. ${ }^{12}$ Legislative rules frequently prescribe, modify, or abolish duties, rights, or exemptions. In contrast, nonlegislative rules do not exercise delegated lawmaking power and thus are not administrative statutes. Instead, they provide gnidance to the public and to agency staff and decisionmakers. They are not legally binding on inembers of the public. ${ }^{13}$

Interpretive rules and policy statements serve distimct functions. An interpretive rule clarifies or explains the meaning of words used im a statute, a previous agency rule, or a judicial or agency adjudicative decision. ${ }^{14}$ A policy statement, on the other hand, indicates how an agency hopes or intends to exercise discretionary power in the course of performing some other administrative function. ${ }^{15}$ For example, a policy statement niight indicate what factors will be considered and what goals will be pursued when an agency conducts investigation, prosecution, legislative rulemaking, or formal or informal adjudication.

Although the theoretical difference between the legal effect of legislative and nonlegislative rules is clear, the practical line-drawing problem

12. See, e.g., Chrysler Corp. v. Brown, 441 U.S. 281 (1979). The Court in Chrysler held that, for purposes of 18 U.S.C. $\S 1905$ (1982), which permits disclosure of information only to the extent "authorized by law," a legislative regulation permitting disclosure is "law" but an interpretive regulation is not. 441 U.S. at 301-03. See also Fidelity Fed. Sav. \& Loan Ass'n v: de la Cuesta, 458 U.S. 141, 154 (1982) (legislative regulation preempts state law); Batterton v. Francis, 432 U.S. 416, 425 n.9 (1977) (limited scope of judicial review of legislative rule). Nonlegislative rules are not "law." See Seegull Mfg. Co. v. NLRB, 735 F.2d 971, 974 (NLRB's treatment of guidelines as "law" is a display of "bureaucratic arrogance"), vacated, 741 F.2d 882 (6th Cir. 1984).

13. Batterton v. Marshall, 648 F.2d 694, 701-02 (D.C. Cir. 1980). See H. Hart \& A. SACHS, THE Legal Process 1315 (Tent. Ed. 1958). The regulations relating to the Federal Register Act supply a helpful definition of "legal effect." A document las "legal effect" if it is "issued under proper autliority prescribing a penalty or course of conduct, conferring a right, privilege, authority, or immunity, or imposing an obligation . . ." 1 C.F.R. $\S 1.1$ (1984).

14. Department of Justice, Attorney General's Manual on the Administrative Procedure ACT 30 n.3 (1947) [hereinafter cited as ATtORNey General's MANUAL on tHe APA]; Guardian Fed. Sav. \& Loan Ass'n v. FSLIC, 589 F.2d 658, 664-65 (D.C. Cir. 1978).

15. See, e.g., ATtorney General's Manual on the APA, supra note 14, at 30 n.3 (policy statements are "issued by an agency to advise the public prospectively of the manner in which an agency proposes to exercise a discretionary power"); DEPARTMENT OF JUSTICE, ATTORNEY GENERAL'S MEMORANDUM ON THE 1974 AMENDMENTS TO THE FREEDOM OF INFORMATION ACT 21 (1975) (policy statements "articulate a settled course of action which would be pursued in a class of matters entrusted to agency discretion"). See also Pacific Gas \& Elec. Co. v. FPC, 506 F.2d 33, 38 (D.C. Cir. 1974). 
has proved difficult for a number of reasons. The most important reason for the haziness of the distinction is that the practical impact of either type of rule on members of the public is the same. Most members of the public assume that all agency rules are valid, correct, and unalterable. Consequently, most people attempt to conform to them rather than to mount costly, time-consuming, and usually futile challenges. Although legislative and nonlegislative rules are conceptually distinct and although their legal effect is profoundly different, ${ }^{16}$ the real-world consequences are usually identical.

Another reason for the confusion surrounding the distinction is that the legal effect of agency rules is often difficult to assess. For example, both legislative and interpretive rules frequently interpret the meaning of language im a statute. ${ }^{17}$ Similarly, both legislative rules and policy statements often prescribe the manner in which an agency will exercise discretionary power. ${ }^{18}$ Moreover, an enormous variety of agency actions can be plausibly characterized as rules. Because their legal effect is difficult to determine, such actions typically resist easy placement in legislative or nonlegislative pigeonholes. ${ }^{19}$

Finally, it often serves the imterests of both agencies and courts to blur or manipulate the distinction between legislative and nonlegislative rules. ${ }^{20}$ In classifymg rules, the "mintention" of the agency is critical, ${ }^{21}$ yet courts understandably have been reluctant to accept an agency's own characterization at face value. ${ }^{22}$ Indeed, the courts themselves have sometimes manipulated the distinction to achieve results sought for other reasons. ${ }^{23}$

16. For example, a court's power to substitute its judgment for that of the agency is much greater in the case of nonlegislative rules. See infra note 59 and accompanying text.

17. See, e.g., Guardians Ass'n. v. Civil Serv. Comm'n, 463 U.S. 582, 592 (1983) (legislative rule defines "discrimination"); Batterton v. Francis, 432 U.S. 416, 419 (1977) (legislative rule defines "unemployment"); Addison v. Holly Hill Fruit Products, Inc., 322 U.S. 607, 608-09 (1944) (legislative rule defines "area of production"); British Caledonian Airways, Ltd. v. CAB, 584 F.2d 982, 991 (D.C. Cir. 1978) ("simplistic" to draw distinction based on whether rule explains statute).

18. See, e.g., Red Lion Broadcasting Co. v. FCC, 395 U.S. 367, 385 (1969) (legislative rules indicate how FCC will apply "public interest" standard). See also infra note 30.

19. See Batterton v. Marshall, 648 F.2d 694, $700-04$ (D.C. Cir. 1980).

20. Agencies are sometimes uncertain whether they possess delegated power or whether they wish to exercise it. See, e.g., Chrysler Corp. v. Brown, 441 U.S. 281, 304-09 (1979).

21. See infra notes 39-40, 60-62 accompanying text.

22. See infra notes $39-46$ and accompanying text.

23. See, e.g., Environmental Defense Fund v. Gorsuch, 713 F.2d 802, 816-17 (D.C. Cir. 1983), discussed infra at notes 50-55 and accompanying text; Jean v. Nelson, 711 F.2d 1455, 1478-83 (11th Cir. 1983) (policy concerning Haitian refugees is legislative rule), vacated as moot on this point, 727 F.2d 957 (11th Cir.), cert. granted, 105 S. Ct. 563 (1984). 


\section{B. Role of Nonlegislative Rules in the Administrative Process.}

Nearly every agency engages constantly in the processes of legal interpretation and the structuring and narrowing of its statutory discretion. The adoption of nonlegislative rules is one way in which an agency might carry out these functions.

1. Interpretation. Interpretation is an indispensable part of administration, because the meaning of language in admimistrative materials is often obscure, ambiguous, or abstract. ${ }^{24}$ To conduct their business, agency heads and staff must fill the gaps, resolve ambiguities, and reduce abstractions to a practical and concrete level.

An agency might simply decide not to deal with an imterpretive problein, leaving the public without guidance and allowing the staff to work things out on a case-by-case basis. However, if it seems worthwhile to arrive at an agreed-upon definition or application of language, an agency unight use one of several techniques. If it has delegated power, it can perform the interpretive function by adopting a definitive legislative rule. It might also interpret language in the course of formal or informal adjudication or by issuing a declaratory order. It can provide interpretive guidance in answering requests for advice by individual meunbers of the public, or it can include interpretive material in instructional manuals.

The final alternative is to adopt and publish a nonlegislative interpretive rule of general apphcability. Countless interpretive rules are adopted each year by federal agencies. Revenue rulings issued by the Internal Revenue Service, advisory opmions about Hatch Act issues by the Merit Systems Protection Board, and interpretive bulletins issued by the Federal Reserve System are three prominent examples. ${ }^{25}$

Interpretive material helps assure consistent day-to-day admimistration by agency staff and provides an invaluable resource for members of the public. Of course, an agency's legal interpretation is not legally binding on anyone; ${ }^{26}$ courts and members of the public are free to disagree with it. In practice, however, an agency's view of the correct resolution of legal questions usually provides the final answer. Few agency interpretations are challenged in court and almost all of those are upheld. ${ }^{27}$

24. See generally M. Asimow, Advice to the PUblic from Federal administrative AGENCIES ch. 1, 2 (1973); Morgenthau, Implied Regulatory Powers in Administrative Law, 28 IowA L. REV. 575 (1943).

25. See $2 \mathrm{~K}$. DAvis, supra note 7 , at $\S 7.4$.

26. In a few instances the interpretation may be binding on the agency itself. See id. at $\S 7.21$.

27. See, e.g., Chevron, U.S.A., Inc. v. Natural Resources Defense Council, 104 S. Ct. 2778, 2782-83 (1984) (deference to reasonable agency policy choice). 
Because the public must live with agency interpretations, it should have the fullest possible access to them. Interpretive rules of general application provide guidance to both staff and pubhic. Their issuance should be encouraged in preference to agency inaction or to providing guidance through such relatively inaccessible sources as informal adjudication, private advice, or staff manuals.

2. Policy Statements. Staff members in most agencies have broad discretion whether to initiate an investigation, audit a return, grant a license, an exemption, or a dispensation, recommend prosecution, or take enforcement action. Agencies may or may not provide guidance to the staff as to how this discretion should be exercised. ${ }^{28}$ An agency might furnish guidance $\mathrm{m}$ a number of ways. It might allow its decisionmakers to exercise the power in the course of conducting fornal or infornial adjudications, or in answering requests for guidance from the public; each such decision would provide some guidance to future decisionmakers, staff, and the public. An agency might also direct the staff by issuing bulletims or imstructions in a manual.

Often, as an agency gams experience in exercising a particular power, it may formulate that experience in more or less precise rules that would guide the staff. At the outset, the guidance might take the form of answers to hypothetical questions about what the staff might do in various circumstances. Alternatively, it inight siniply provide a checklist or itemize the factors to be taken into account without explaining how to weigh them. ${ }^{29}$ Later, an agency may state tentative standards in the form of a nonlegislative rule. Ultimately, an agency may be willing to commit itself to a legislative rule that definitively and rigidly prescribes how the power will be exercised. ${ }^{30}$

Policy statements are nonlegislative rules that tentatively indicate

28. Of course, even if an agency furnishes no guidance to staff members, the people who must make the decisions usually evolve a set of guidelines for themselves. Often, one or a few staff members will accumulate expertise in dealing systematically with recurring problems. See Gifford, Decisions, Decisional Referents, and Administrative Justice, 37 LAw \& ConTEMP. Prons. 3, 5-11 (1972) (discussing the constraints that are internally developed by those to whom administrative authority is delegated).

29. See, e.g., Proposed Rules of the Immigration and Naturalization Service, 44 Fed. Reg, 36,187 (1979), withdrawn, 46 Fed. Reg. 9119 (1981).

30. Discretionary functions are often the subject of legislative mles. See, e.g., Diver, The Optimal Precision of Administrative Rules, 93 YALE L.J. 65, 92-97 (1983) (limiting discretion in immigration cases). The progression from less to more rigid confinement of discretion is described in $K$. Davis, Discretionary Justice: A PReliminary InQuiry 59-64 (1969). For the classic description of incremental deeisionmaking, see Lindbloin, The Science of "Muddling Through," 19 PuB. AD. REV. 79, 80-88 (1959). 
how agency decisionmakers will exercise a discretionary power. ${ }^{31}$ Such rules might, for example, isolate the factors that should be considered in making decisions, rank priorities, set tolerance levels, explam when dispensations should be granted, build flexibility into overly rigid rules, indicate what data are relevant, or otherwise narrow the available decisional referents that must be taken into account. Some familiar examples are the policy statements adopted by the Federal Communications Commission, the Operations Instructions of the Immigration and Naturalization Service, the Merger Guidelines and the FBI Investigative Guidelines of the Department of Justice, and the revenue procedures published by the Internal Revenue Service. ${ }^{32}$

Agencies frequently consider whether a discretion-structuring rule should be adopted or made inore precise. Certainly, greater precision entails significant costs, mcluding the bureaucratic costs of formulating a rule. ${ }^{33}$ Formulation costs are often steep, because the staff members who have dealt with the problem may themselves be uncertain precisely why and how they do what they do. In addition, discretion-confining rules may be over-or under-inclusive, decisionmaking under the rule may be unjustifiably rigid, ${ }^{34}$ and the rule may highlight loopholes. Nevertheless, commentators generally agree that agencies should face and resolve the questions of how discretion will be exercised inuch more frequently than they do at present, ${ }^{35}$ a process that offers advantages to both the agency

31. Statements of general policy must be currently published in the Federal Register. 5 U.S.C. $\S 552(\mathrm{a})(1)(\mathrm{D})$. Otlier statements of policy (presumably those that are particular rather than general) must be made available for public inspection and copying. 5 U.S.C. $\S 552(\mathrm{a})(2)(\mathrm{B})$. On the publication requirement, see Comment, Publication Under the Freedom of Information Act of Statements of General Policy and Interpretations of General Applicability, 47 U. CH1. L. REV. 351 (1980); Note, A Model for Determining the Publication Requirements of Section 552(a)(1) of the Administrative Procedure Act, 13 Mich. J. L. REF. 515 (1980).

32. See, e.g., Eliff, The Attorney General's Guidelines for FBI Investigations, 69 CORNELL L. REv. 785 (1984). A detailed account of the practices of four agencies in using interpretive rules and policy statements appears in Asimow, supra note 7, at 524-28 (discussing IRS, INS, FCC, and FTC practices).

33. See infra notes $111-13$ and accompanying text.

34. See Cancellation of proposed rule by the Imınigration \& Naturalization Service, 46 Fed. Reg. 9119 (1981) (guidelines inay become so rigid as to amount to abuse of discretion); E. BARDACH \& R. KAGAN, GOING BY THE BOOK 58-119 (1982) (discussion of practical problems inherent in rigid enforceinent); Diver, supra note 30, at 71-76.

35. Most coininentators believe that the benefits of supplying additional structure usually outweigh the costs of doing so and thus urge agencies to confine discretion far unore often than they do. For perspectives froin political science, economics, public administration, and law, see generally $P$. Cooper, Public Law and Public Administration 213-32 (1983); K. Davis, supra note 30; T. Lowi, The END of Liberalism 10-19, 302-05 (2d ed. 1979); G. Tullock, The Politics of BUREAUCRACY 180-85 (1965); Diver, supra note 30, at $92-97$ (advocating clearer standards to constrain INS discretion to change alien status); Gifford, Discretionary Decisionmaking in the Regulatory Agencies: A Conceptual Framework, 57 S. CAL. L. REv. 101, 102-34 (1983) (analysis of which discretionary powers lend themselves to structure); Schuck, When the Exception Becomes the Rule: 
and the public.

For the agency, the very process of considering how a particular power might be structured often results in a productive process of selfcriticism and the generation of alternatives and fresh points of view. ${ }^{36}$ If an agency can reach consensus on how to confine discretion, the personnel who must exercise it are more likely to do so consistently and fairly. In addition, policy statements tend to minimize the inevitable distortions of agency priorities that result from a multilevel delegation within an institution. Moreover, an informed public is more likely to conform voluntarily to the law, thus minimizing enforcement costs. ${ }^{37}$

To the public that must live with an agency's discretionary power, knowledge of how that power will be used is extremely valuable. It opens a wimdow on an agency's decisional process and thus enables a person who is detrimentally affected to make an informed argument to the correct staff member that an exception should be made. It permits everyone who must deal with the agency equal access to vital information, thus diminishing the advantage held by experienced professionals or former agency staff members. Finally, pohicy statements enable the pubhic to plan transactions with more precise knowledge of how agencies will react. As a result, a person subject to regulation or seeking a benefit is less likely to encounter difficulties with the agency. To the extent that disputes between government and regulated parties can be avoided through proper advance planning, both sides avoid the deadweight loss associated with dispute settlement and thwarted plans. ${ }^{38}$

General policy statements are well calculated to control staff action and, because they must be published in the Federal Register, to inform the public. They provide authoritative guidance on what the staff is likely to do, yet unlike legislative rules they remain tentative, not rigid. Consequently, they leave decisionmakers room for flexible application; they do not foreclose further experimentation and learning from experience.

Regulatory Equity and the Formulation of Energy Policy Through an Exceptions Process, 1984 DUKE L.J. 163, 268-69, 294-98; Sofaer, Judicial Control of Informal Discretionary Adjudication and Enforcement, 72 CoLUM. L. REv. 1293, 1295 (1972) (unconfined discretion led to inconsistency, political intervention, high reversal rates, extra decisional costs, and severely disadvantaged unrepresented aliens); Note, Regulatory Values and the Exceptions Process, 93 YALE L.J. 938 (1984).

36. See Gifford, supra note 28 , at 22-26, 29-30.

37. See Hirsch, Reducing Law's Uncertainty and Complexity, 21 UCLA L. REv. 1233, 1234-36 (1974).

38. See Ehrlich \& Posner, An Economic Analysis of Legal Rulemaking, 3 J. OF LEGAL STUD. $257,262-67$ (1974). 


\section{Judicial Techniques for Drawing the Legislative/ NONLEGISLATIVE DisTINCTION}

As we have seen, the theoretical difference between legislative and nonlegislative rules is clear. Legislative rules exercise delegated legislative power; nonlegislative rules do not. In many instances, an agency can choose to proceed legislatively or nonlegislatively, and there can be little dispute over the characterization of the resulting product: The agency explicitly declares that it intends to act either legislatively or nonlegislatively and that declared intention corresponds with the legal effect of the rule.

Unfortunately, a substantial number of cases remain in which the decision whether a rule is legislative or nonlegislative is considerably more difficult. This section outlines two different approaches to the problein-the prevailing legal effect standard and the increasingly rejected substantial impact test. An appreciation of the difficulties encountered in applying these tests is helpful in assessing proposed regulatory reform of the procedures for adopting nonlegislative rules.

\section{A. The Agency's Label.}

When an agency has a choice to proceed legislatively or nonlegislatively, its contemporaneous description is the inost rehiable test of what it actually did. ${ }^{39}$ Because an agency can choose to interpret law or limit discretion through legislative rulennaking, nonlegislative rulennaking, adjudication, or other techniques, it is appropriate to accept the agency's description of which alternative it chose at the time it made the choice. Deference to the agency's label also proinotes certainty and predictability of result and provides agencies with reasonable assurance that reviewing courts will honor their decision to proceed nonlegislatively. Thus, an agency's contemporaneously-adopted ${ }^{40}$ description of its intention and

39. See, e.g., American Trucking Ass'n v. United States, 688 F.2d 1337, 1344 (11th Cir. 1982) (interpretive rule), reversed on other grounds, 104 S. Ct. 2458 (1984); British Caledonian Airways, Ltd. v. CAB, 584 F.2d 982, 992 (D.C. Cir. 1978)(declaratory order); Pacific Gas \& Elec. Co. v. FPC, 506 F.2d 33, 39 (D.C. Cir. 1974)(policy statement). See Chrysler Corp. v. Brown, 441 U.S. 281, 31216 (1979)(rule interpretive because agency so treated it). However, the Senate Judiciary Comnittee lias sharply criticized undue judicial deference to an agency's label. See The Regulatory Reform Act, S. Rep. No. 284, 97th Cong., 1st Sess. 113 (1981) [hereinafter cited as SENATE REPORT].

40. Subsequent characterizations by couusel are nuch less persuasive. See Regular Common Carrier Conference of the Am. Trucking Ass'n. v. United States, 628 F.2d 248, 251 (D.C. Cir. 1980). In Levesque v. Block, 723 F.2d 175, 179-81 (1st Cir. 1983), the court gave no deference to a "latearising" claim that a rule was interpretive. According to the decision by Judge McGowan, late characterizations mislead the public, which is entitled to know whether a rule is legislative or not. Deference to a post-loc cliaracterization encourages an agency to "act now, make up reasons later." "Id. at 180. 
desired legal effect is and should be of central importance in characterizing its product.

Unfortunately, a court cannot always rely on labels to distinguish between legislative and nonlegislative rules. Agencies nay provide vague or contradictory descriptions of their rules, or may fail to characterize their pronouncements at all. ${ }^{41}$ Moreover, an agency, unsure whether it has delegated power or, if it does, whether it wishes to exercise it, may try to disguise the issue by failing to describe its product clearly. In other cases, confusion may be caused by poor staff work. For example, staff members may fail to clarify whether a pronouncement that amplifies a legislative rule is intended to amend the rule or merely to interpret it. Finally, an agency might overlook the fact that a rule labelled as nonlegislative is, for some reason, legally binding on someone or some other agency, and cannot properly be treated as nonlegislative. ${ }^{42}$

Thus, many courts have declared that labels are entitled to judicial deference, but cannot be dispositive of the issue of the proper characterization of a rule. ${ }^{43}$ Courts consistently question whether the chosen label correctly describes the legal effect of a particular rule. Otherwise, an agency might mampulate its description in order to avoid pre-enforcement judicial review, ${ }^{44}$ keep a low profile, ${ }^{45}$ or circumvent cumbersome notice and comment requirements, ${ }^{46}$ while achieving the desired change in staff and private party behavior.

\section{B. Policy Statements: The Definitiveness Test.}

Policy statements and many legislative rules are addressed to discretionary functions. A difficult characterization problem is often presented when an agency with delegated legislative power chooses to adopt a pol-

41. See, e.g., Jean v. Nelson, 711 F.2d 1455, 1482 (11th Cir. 1983), vacated as moot on this issue, 727 F.2d 957, 962 (11th Cir.), cert. granted, 105 S.Ct. 563 (1984).

42. See, e.g., Batterton v. Marshall, 648 F.2d 694, 704-06 (D.C. Cir. 1980).

43. See, e.g., First Bancorp. v. Board of Governors of the Fed. Reserve Sys., 728 F.2d 434, 438 (10th Cir. 1984) (pohcy statement in informal adjudication treated as legislative rule); American Bus Ass'n v. United States, 627 F.2d 525, 531 (D.C. Cir. 1980) (pohicy statement treated as legislative rule); Chamber of Commerce v. OSHA, 636 F.2d 464, $468-69$ (D.C. Cir. 1980) (interpretive rule treated as legislative); Joseph v. United States Civil Serv. Comm'n, 554 F.2d 1140, 1153 (D.C. Cir. 1977) (same).

44. A legislative rule is more likely than a nonlegislative rule to be held ripe for judicial review before it is applied, although many nonlegislative rules have been held to meet the ripeness test. See infra note 213; Asimow, supra note 7, at 567-69.

45. See First Bancorp. v. Board of Governors of the Fed. Reserve Sys., 728 F.2d 434, 438 (10th Cir. 1984) (Board attempted to announce significant policy change through informal adjudication); Jean v. Nelson, 711 F.2d 1455, 1470-82 (11th Cir. 1983) (INS consciously chose not to promulgate rule after making policy clrange), vacated as moot on this issue, 727 F.2d 957, 962 (11th Cir.), cert. granted, 105 S. Ct. 563 (1984).

46. See, e.g., Environmental Defense Fund v. Gorsuch, 713 F.2d 802, 816 (D.C. Cir. 1983). 
icy stateinent without prior notice and comment. The prevailing criterion for analyzing this issue is the "definitiveness" test. If the court finds that a discretionary power has been tentatively limited, the agency's pronouncement is a policy statement; if it finds that the power is definitively limited, the pronouncement is a legislative rule. ${ }^{47}$

The definitiveness rule clearly leaves much to be desired as a manageable and predictable standard for judicial decisionmaking. Because it hinges on whether a rule definitively or tentatively channels discretion, the test requires a prediction of the agency's future behavior, and the result will often turn on whether the staff used mandatory or precatory language. 48

On the other hand, the definitiveness test has some positive aspects. It provides a serviceable roadmap by which agencies can confine discretionary power without inviting advance public participation. An agency can be reasonably certain that notice and comment procedure will not be required if it labels a discretion-structuring rule as a policy statennent, builds in assurances that the rule is tentative, and treats it in actual practice as tentative.

In addition, the definitiveness test has a certaim compelling logic. If the public is derried an advance opportumity to influence a policy stateinent, it should have a fair chance to persuade a decisionmaker to follow a different course when the discretionary function is actually exercised im a subsequent investigation, formal or inforinal adjudication, or other proceeding.

Several factors are helpful in applying the definitiveness test. One is a reaistic assessinent of the tentativeness of a rule. Rules that seein tentative or suggestive, leaving room for decisionmakers to exercise judgment, are properly characterized as policy statements..$^{49}$ In contrast, a

47. See, e.g., Simmons v. ICC, 757 F.2d 296, 300 (D.C. Cir. 1985) (agency cannot treat policy statelnent as binding authority in later rulentaking); American Bus Ass'n. v. United States, 627 F.2d 525, 531-32 (D.C. Cir. 1980).

48. The "definitiveness test" las frustrated a number of courts. See e.g., Jcan v. Nelson, 711 F.2d 1455, 1480 (11tl Cir. 1983) (test is a inorass "akin to wandering lost in a serbonian bog"), yacated as moot on this point, 727 F.2d 957, 962 (11tl Cir.), cert. granted, 105 S. Ct. 563 (1984); American Bus Ass'n v. United States, 627 F.2d 525, 528-29 (D.C. Cir. 1980) (drawing the line is "liazardous"); Guardian Fed. Sav. \& Loan Ass'n v. FSLIC, 589 F.2d 658, 667-68 (D.C. Cir. 1978) (test calls for intuitive judgment); Noel v. Chapinan, 508 F.2d 1023, 1030 (2d Cir.) (test is "enshrouded in considerable snıg"), cert. denied, 423 U.S. 824 (1975); Pacific Gas \& Elec. Co. v. FPC, 506 F.2d 33, 37 (D.C.Cir. 1974) (distinction is a "fuzzy product") (quoting 1 K. Davis, AdmINIsTRATIVE LAW $\S 5.01$, at 290 (2d ed. 1958)).

49. See, e.g., Ryder Truck Lines v. United States, 716 F.2d 1369, 1376-78 (11tl Cir. 1983); Burroughs Welcone Co. v. Scliweiker, 649 F.2d 221, 225 (4tlı Cir. 1981); Guardian Fed. Sav. \& Loan Ass'n. v. FSLIC, 589 F.2d 658, 666-68 (D.C. Cir. 1978); Pacific Gas \& Elec. Co. v. FPC, 506 F.2d 33, 38-43 (D.C. Cir. 1974). See also Asimow, supra note 7, at 540 n.87. 
rule adopted by an agency with legislative rulemaking power that appears to preclude the exercise of discretion, prescribes how it must be exercised, or leaves no administrative forum in which the exercise of discretion can be challenged, should be considered legislative.

Consider, for example, Environmental Defense Fund v. Gorsuch, ${ }^{50}$ a case that allowed the court to play a role in the pohtical struggles that engulfed the Environmental Protection Agency (EPA) early in the Reagan Administration. A statute required EPA to set standards for hazardous waste processing and also required waste processors to meet EPA's standards in order to apply for licenses. Existing processors were permitted to operate with temporary licenses until EPA adopted the standards and called in their temporary licenses.51 EPA duly adopted standards, but under political pressure from the Office of Management and Budget (OMB), gave notice that it proposed to suspend thein. It also announced as a matter of "policy" that because the regulatory standards that would condition permanent licenses might be suspended, EPA would defer callmg im the temporary processing licenses. ${ }^{52}$

EPA defended the "policy" as a reasonable resource allocation: It was reluctant to issue permanent licenses conditioned on compliance with standards that it proposed to suspend. The EPA also observed that its "policy" was not definitive, because it was free to call in tle teinporary license of any particular processor. ${ }^{53}$

Declaring that APA exemptions should be strictly construed, particularly where an agency reverses its position, the court lield that the substance of the "policy" was an indefinite exemption of the processors from meeting the standards that EPA had already adopted and that Congress intended would be observed to protect public health. 54 The "policy" was not likely to be waived and there was no obvious proceeding in whicl the issue might even be raised. In short, the court held that EPA's "policy"

50. 713 F.2d 802, 816-17 (D.C. Cir. 1983). See also Jean v. Nelson, 711 F.2d 1455, 1478-83 (11th Cir. 1983), vacated as moot on this point, 727 F.2d 957 (11th Cir.), cert. granted, 105 S. Ct. 563 (1984); Independent U.S. Tanker Owners Comm'n v. Lewis, 690 F.2d 908, 918 (D.C. Cir. 1982); Chamber of Commerce v. OSHA, 636 F.2d 464, 467 n.4 (D.C. Cir. 1980); Brown Express, Inc. v. United States, 607 F.2d 695, 701 (5th Cir. 1979); Dow Chemical v. CPSC, 459 F. Supp. 378, 392-93 (W.D. La. 1978); United States ex rel. Parco v. Morris, 426 F. Supp. 976, 984-85 (E.D. Pa. 1977). But see Davis Walker Corp. v. Blumenthal, 460 F. Supp. 283, 294 (D.D.C. 1978) (upholding rigid "trigger price mechanism" as policy statement). In Pickus v. United States Bd. of Parole, 507 F.2d 1107, 1114 (D.C. Cir. 1974), an early decision based primarily on substantial impact analysis, the court held that rules which tightly (but not definitively) limited the discretion of parole decisionmakers could not be treated as policy statements.

51. See Environmental Defense Fund v. Gorsuch, 713 F.2d 802, 805, 806 (D.C. Cir. 1983).

52. See id. at 808.

53. See id. at 816 .

54. Id. at 816-17. 
was definitive, not tentative, and, as a legislative rule, was invalid for want of advance notice and comment procedure. 55

A second factor that courts take into account when deciding whether a rule that confines a power is tentative or definitive is the precise wording used by the agency. For example, a rule that uses rebuttable presumptions, ${ }^{56}$ or that uses words of suggestion, like "may" or "should consider," rather than inflexible words of command, 57 is likely to be a policy statement.

A third factor that courts may consider is actual administrative experience in applying a rule. If agency decisionmakers seem genuinely open to contrary suggestions in subsequent proceedings, a rule is likely to be a policy statement. If, however, decisionmakers appear to view themselves as bound by the rule, it inay be treated as legislative. ${ }^{58}$

\section{Interpretive Rules: Legal Effect Test.}

When a court reviews a language-interpreting rule that was adopted by an agency with legislative rulemaking power, it must begin by characterizing the rule. Most importantly, whether a rule is legislative or inter-

55. See id. at 817-18.

56. See Regular Common Carrier Conference of the Am. Trucking Ass'n. v. United States, 628 F.2d 248 (D.C. Cir. 1980); Ryder Truck Lines v. United States, 716 F.2d 1369, 1376-78 (11th Cir. 1983), cert. denied, 104 S. Ct. 1707 (1984).

57. See Guardian Fed. Sav. \& Loan Ass'n. v. FSLIC, 589 F.2d 658, 666 (D.C. Cir. 1978); American Bus Ass'n. v. United States, 627 F.2d 525, 531-32 (D.C. Cir. 1980). The American Bus decision drew support from the famous case of Columbia Broadcasting Sys., Inc. v. United States, 316 U.S. 407 (1942). See American Bus, 627 F.2d at 530-31 (discussing CBS). The CBS Court permitted pre-enforcenent review of legislative rules despite the fact that the FCC had labelled then policy statements, because they were definitive rather than tentative and contained niandatory language. See 316 U.S. 407, 416-20 (1942).

58. See Jcan v. Nelson, 711 F.2d 1455, 1482-83 (11th Cir. 1983), vacated as moot on this point, 727 F.2d 957, 963 (11th Cir.), cert. granted, 105 S. Ct. 563 (1984); American Bus Ass'n. v. United States, 627 F.2d 525, 532 (D.C. Cir. 1980).

A few other factors have occasionally been suggested, but these appear relatively unhelpful. Where a rule is styled as a teinporary or interim solution to a problem, it is less likely to be considered legislative than one that operates indefinitely or permanently. See E. TomLINson, FinaL REPORT IN SUPPORT OF RECOMMENDATION 76-2 STRENGTHENING THE INFORMATIONAL AND Notice GIVING Functions of THE FEDERAL Register, 4 Recommendations and RePORTS of the Administrative Conference of the UNITEd States: July 1, 1974 - December 31, 1977427,463 (1976) (the operative life of policy statenent should be short); Dow Cheln. v. CPSC, 459 F. Supp. 378, 392 (W.D. La. 1978). A rule addressed to agency staff is more likely to be a policy statement that one addressed to the public. See Noel v. Chapinan, 508 F.2d 1023, 1030 (2d Cir.), cert. denied, 423 U.S. 824 (1975); Bonfield, supra note 7, at 115. Finally, sone courts have indicated that a policy statement with present as well as prospective effect is a legislative rule. See, e.g., Brown Express, Inc. v. United States, 607 F.2d 695, 701 (5th Cir. 1979). However, this approach seeins misconceived. A rule is a policy statement if it tentatively channels discretionary action; whether that action is part of an ongoing proceeding, or only one contemplated in the future, seems unimportant. See Jcan v. Nelson, 711 F.2d at 1478, 1482. 
pretive determines whether the court must defer to the agency's policy judgments or whether the court can substitute its own judgments. ${ }^{59}$ In addition, of course, the appropriate procedure for adopting the rule turns on whether it is legislative or interpretive.

The prevailing standard for distinguishing legislative and interpretive rules can be described as the "legal effect" test. If a rule explaining the meaning of language actually makes "new law," as opposed to merely interpreting "existing law," it is legislative. Because both legislative and mterpretive rules frequently explain the meaning of language, ${ }^{60}$ there is no obvious way to determine whether an agency with legislative rulemaking power has made "new law" or interpreted "existing law."61 Thus, the result often turns on whether an agency "intended" to make new law, and that determination necessarily must depend primarily on the label that the agency attached to its product. ${ }^{62}$

Courts confront the characterization issue in two distinct situations-rules that explain the meaning of a statute and rules that explain the meaning of a previous legislative rule.

1. Rules That Explain Statutes. In considering whether a rule that explains a statute is interpretive, courts consider a number of factors in addition to the agency's label or an assessment of its intention. A rule makes "new law," as opposed to interpreting "existing law," if it fills a statutory gap by imposing a standard of conduct, creating an exemption from a standard of conduct, erecting a new regulatory structure, or otherwise implementing congressional policy by completing an incomplete statutory design. ${ }^{63}$ Suppose, for example, that Congress allows an agency to exempt certain transactions from the coverage of a regulatory statute. Without a rule, such transactions would not be exempt. A rule

59. See, e.g., Batterton v. Francis, 432 U.S. 416, 424-26 (1977); General Elec. Co. v. Gilbert, 429 U.S. 141 (1976). See also infra notes 160-69 and accompanying text.

60. See supra note 17 and accompanying text.

61. One judge has criticized this standard as a "riddle." See Chisholin v. FCC, 538 F.2d 349, 393 (D.C. Cir.) (Wright, J., dissenting), cert. denied, 429 U.S. 690 (1976).

62. See, e.g., General Motors Corp. v. Ruckelshaus, 742 F.2d 1561, 1565 (D.C. Cir. 1983) ("if by its action the agency intends to create new law . . . the rule is properly considered to be a legislative rule"), cert. denied, 105 S. Ct. 2153 (1985); Levesque v. Block, 723 F.2d 175, 182-83 (1st Cir. 1983) (rehiance on good cause exeinption suggests agency intended legislative effect). On the other hand, omission of notice and comment would suggest that the agency did not intend legislativc effect. See Board of Educ. v. Harris, 622 F.2d 599, 613 (2d Cir. 1979).

63. See Cabais v. Egger, 690 F.2d 234, 239 (D.C. Cir. 1982) (detailed rules establishing mathematical formulae for determining individual contributions to pension funds are legislative); Batterton v. Marshall, 648 F.2d 694, 705-06 (D.C. Cir. 1980); Chamber of Commerce v. OSHA, 636 F.2d 464, 469 (D.C. Cir. 1980); Citizens to Save Spencer County v. EPA, 600 F.2d 844, 877-79 (D.C. Cir. 1979). 
spelling out an exemption would necessarily be legislative. ${ }^{64}$

As a consequence, the more vague and open-textured a statute, the more likely that a rule implementing it will be legislative rather than interpretive. ${ }^{65}$ On the other hand, if the statutory provision in issue is detailed, leaving relatively little rooin for agency implementation, a rule explaining the statute is inore likely to be considered interpretive. 66 Similarly, a rule that conforms closely to the language of the statute is likely to be considered a mere reminder and thus interpretive. ${ }^{67}$

Another relevant factor in distinguishing between legislative and interpretive rules is the specificity with which an agency's delegated legislative power has been expressed. In many cases, legislative rulemaking power is conferred by a specific statutory provision. ${ }^{68}$ In other instances, however, a statute provides only a general ruleinaking authority apphicable to the entire statute; under the prevailing view, at least im the federal courts, general ruleınaking provisions einpower an agency to make either interpretive or legislative rules. ${ }^{69}$ Several courts have indicated that, in doubtful cases, rules made pursuant to specific rulemaking powers are inore likely to be treated as legislative than are rules made pursuant to general ruleinaking powers. ${ }^{70}$

64. See Joseph v. United States Civil Serv. Comm'n, 554 F.2d 1140, 1153-55 (D.C. Cir. 1977) (Hatch Act delegated authority to exempt government eniployees from provisions of act; rules promulgated pursuant to such delegation are legislative).

65. See American Trucking Ass'n v. United States, 688 F.2d 1337, 1344 n.12 (11th Cir. 1982), rev'd on other grounds, $104 \mathrm{~S}$. Ct. 2458 (1984).

66. See American Postal Workers Union v. United States Postal Serv., 707 F.2d 548, 559 (D.C. Cir. 1983), cert. denied, 104 S. Ct. 1594 (1984).

67. See Alcaraz v. Block, 746 F.2d 593, 613 (9th Cir. 1984); Cabais v. Egger, 690 F.2d 234, 238 (D.C. Cir. 1982); Citizens to Save Spencer County v. EPA, 600 F.2d 844, 876 n.153 (D.C. Cir. 1979). But see Levesque v. Block, 723 F.2d 175, 182 (1st Cir. 1983) (rule that restates statute is legislative because it supplied effective date).

68. Such statutes typically contain wording like "pursuant to rules adopted by the secretary."

69. See, eg., National Nutritional Foods Ass'n. v. Wemberger, 512 F.2d 688, 695 (2d Cir.), cert. denied, 423 U.S. 827 (1975); National Petroleum Refiners Ass'n. v. FTC, 482 F.2d 672, 676-78 (D.C. Cir. 1973), cert. denied, 415 U.S. 951 (1974). However, the general rulentaking power in the Internal Revenue Code has been interpreted to confer authority only to adopt niterpretive rules. See Rowan Cos., Inc. v. United States, 452 U.S. 247, 253 (1981).

70. See Alaniz v. Office of Personnel Manageinent, 728 F.2d 1460, 1468 n.6 (Fed. Cir. 1984); Levesque v. Block, 723 F.2d 175, 183 (1st Cir. 1983); Chisholm v. FCC, 538 F.2d 349, 393 (D.C. Cir.) (Wright, J., dissenting), cert. denied, 429 U.S. 890 (1976). Cf. Chrysler Corp. v. Brown, 441 U.S. 281, 303-12 (1979).

A few other criteria have influenced courts to find that a rule did or did not have legislative effect. Where a rule defied a definitive judicial construction of a statute, it conld only be legislative in effect. See Chamber of Commerce v. OSHA, 636 F.2d 464, $468-69$ (D.C. Cir. 1980). Because administrative interpretation is always subject to judicial reassessinent, an interpretation that conld not be judicially reviewed might well be legislative. See General Motors Corp. v. Ruckelshaus, 724 F.2d 979, 984 n.30 (D.C. Cir. 1983) (because judicial review is possible, rule could be nuterpretive), rev'd on other grounds upon hearing en banc, 742 F.2d 1561 (D.C. Cir. 1984), cert. denied, 105 S. Ct. 2153 (1985). A rule that is binding on other agencies, such as state welfare departments, necessarily has 
2. Rules That Explain Rules. Many rules explain or clarify previous legislative rules. ${ }^{71}$ If a second rule repudiates or is irreconcilable with the prior one, the second rule must be an amendment of the first; and, of course, an amendment to a legislative rule must itself be legislative. ${ }^{72}$ Usually, however, the second rule is consistent with the earlier one. In such cases there is no principled way to determine whether it amends the prior rule or merely explams, clarifies, or interprets it, ${ }^{73}$ and courts by necessity usually defer to an agency's characterization of its imtent. ${ }^{74}$

On occasion, courts find second rules legislative when they deal with a matter not clearly covered by an earher legislative rule. For example, Standard Oil Co. v. Department of Energy ${ }^{75}$ concerned petroleum price controls. The Department had established legislative rules allowing petroleum sellers to raise prices in order to recover cost increases, but permitting greater price imcreases if the cost mcrease was in product rather than nonproduct costs. However, the legislative rules failed to specify how to determine whether a price increase was traceable to an increase in product or nonproduct costs when both costs had increased. The agency issued a subsequent rule, labelled as "interpretive," to solve the problem, but the Temporary Emergency Court of Appeals held that it was legislative, because the issue had not been covered in the prior legislative rule. ${ }^{76}$ The Standard Oil case is unusual; most decisions simply declare the second rule consistent with the first and thus interpretive. The decision

legislative effect. See Cabais v. Egger, 690 F.2d 234, 239 (D.C. Cir. 1982) (rule held to be legislative because it limited state discretion and imposed obligation on states not found in statute itself); Aiken v. Obledo, 442 F. Supp. 628, 649 (E.D. Cal. 1977). A rule that is consistent with prior agency practice is likely to be interpretive since it does not create "new rights or duties." General Motors v. Ruckelshaus, 742 F.2d at 1565 . Finally, a rule that relates to the scope of an agency's delegated power is usually interpretive, because a court should have plenary power to inake the ultinate decision on this issue. See Allied Van Lines v. ICC, 708 F.2d 297, 300 (7th Cir. 1983).

71. A rule changing a prior interpretive rule would generally be interpretive. See American Postal Workers Union v. United States Postal Serv., 707 F.2d 548, 558-59 (D.C. Cir. 1983), cert. denied, 104 S. Ct. 1594 (1984). On the other hand, a rule that replaces a repealed legislative rule is likely to be legislative. See Levesque v. Block, 723 F.2d 175, 183 (1st Cir. 1983).

72. See Alaniz v. Office of Personnel Manageinent, 728 F.2d 1460, 1468 (Fed. Cir. 1984); Detroit Edison Co. v. EPA, 496 F.2d 244, 248 (6th Cir. 1974).

73. The leading case states the "test" in conclusory terms: An interpretive rule is an agency's opinion as to the ineaning of an existing rule, whereas a legislative rule creates new law. See Gibson Wine Co. v. Snyder, 194 F.2d 329, 331-32 (D.C. Cir. 1952). But see id. at 335 (second rule so clearly at variance with the earher rule that the second one could not be an interpretation) (Miller, J., dissenting). See also Asiniow, supra note 7, at 545 n.107.

74. See, e.g., Viacom Int'1. Inc. v. FCC, 672 F.2d 1034, 1042 (2d Cir. 1982); Carter v. Cleland, 643 F.2d 1, 8-9 (D.C. Cir. 1980); Energy Reserves Group, Inc. v. Departinent of Energy, 589 F.2d 1082, 1092-93 (Teinp. Einer. Ct. App. 1978).

75. 596 F.2d 1029, 1035 (Teinp. Einer. Ct. App. 1979).

76. Id. at 1061 . 
seemed influenced by the substantial impact of the rule on regulated parties, the subject addressed in the next section.

In many cases, a court that reviews a second rule may avoid the procedural problein entirely by merging it with the issue of substantive validity. If the court finds the second rule consistent with the first one, it follows both that the second rule is interpretive and also that it is substantively valid. ${ }^{77}$ If the second rule is inconsistent with the first one, it is invalid both for procedural reasons (because it was an amendment adopted without notice and comment) and substantive reasons (it could not be a valid interpretation of the earher rule if inconsistent with it).

\section{The Substantial Impact Test.}

As we have seen, the prevailing test used to distinguish legislative and nonlegislative rules centers on the legal effect that an agency intended the rule to have. A conflicting line of cases holds that the critical factor in drawing the distinctions is the substantiality of the practical impact of a rule. Under this approach, pre-adoption procedure is required if a rule has a substantial practical impact on a significant body of regulated persons. ${ }^{78}$

The substantial impact test enjoyed a considerable vogue in the early to middle 1970's. Since then, courts have cautiously but consistently rejected it in deciding whether to require notice and comment procedure before adoption of a purportedly nonlegislative rule. ${ }^{79}$ Nevertheless, the

77. See Avoyelles Sportsmen's League v. Marsh, 715 F.2d 897, 910-13 (5th Cir. 1983); National Retired Teachers' Ass'n v. United States Postal Serv., 593 F.2d 1360, 1364-65 (D.C. Cir. 1979).

78. See, e.g., Pickus v. United States Bd. of Parole, 507 F.2d 1107, 1113-14 (D.C. Cir. 1974); Pharmaceutical Mfrs. Ass'n v. Finch, 307 F. Supp. 858, 863 (D. Del. 1970). By statute, the Federal Energy Admmistration at one time had to furnish an opportumity for oral presentation of views, data, and argunents before adoptimg a rule that would have a substantial impact on the economy or on large numbers of individuals or businesses. See 15 U.S.C. $\S 766(i)(1)(C)(1970)$, repealed by Pub. L. No. 95-91, § 709(a)(1)(c), 91 Stat. 565, 608 (1977). For a case holding an agency rule imvalid due to failure to comply with this statutory requirement of opportunity for oral presentation of views, see Shell Oil Co. v. Federal Energy Admin., 574 F.2d 512 (Temp. Emer. Ct. App. 1978).

79. See, e.g., Rivera v. Becerra, 714 F.2d 887, 890-91 (9th Cir. 1983), cert. denied, 104 S. Ct. 1591-92 (1984); American Postal Workers Umion v. United States Postal Serv, 707 F.2d 548, 559-60 (D.C. Cir. 1983), cert. denied, 104 S. Ct. 1594 (1984); Cabais v. Egger, 690 F.2d 234, 237-38 (D.C. Cir. 1982); American Trucking Ass'n v. United States, 688 F.2d 1337, 1351-52 \& n.20 (11th Cir. 1982) (stating that the substantial impact test is "only one, weakly relevant consideration im the legislative rule determination"), rev'd on other grounds, 104 S. Ct. 2458, 2468 (1984); Energy Reserves Group, Inc. v. Department of Energy, 589 F.2d 1082, 1093-98, 1102-03, 1103-12 (Temp. Emer. Ct. App. 1978) (plurality opinion rejects substantial impact test but concurring and dissenting opinions accept it); Eastern Kentucky Welfare Rights Org. v. Simon, 506 F.2d 1278, 1290 n.30 (D.C. Cir. 1974), vacated on other grounds, 426 U.S. 26, 44-46 (1970). But see Batterton v. Marshall, 648 F.2d 694, 708 (D.C. Cir. 1980); Standard Oil Co. v. Department of Energy, 596 F.2d 1029, 1061 (Temp. Emer. Ct. App. 1979); Chisholm v. FCC, 538 F.2d 349, 394 (D.C. Cir.) (dissenting opinion), cert. denied, 429 U.S. 890 (1976). 
substantial impact test remaims important for a number of related purposes. It is a factor in deciding whether the procedural ${ }^{80}$ or good cause exemptions ${ }^{81}$ apply. It is also relevant in deciding whether a procedural defect should be overlooked as a harmless error, ${ }^{82}$ whether a nonlegislative rule must be published in the Federal Register, ${ }^{83}$ and whether a retroactive legislative rule is valid. ${ }^{84}$ Finally, the substantial impact test is useful as a guide to agencies in deciding whether voluntarily to invite public participation before adopting a particularly important nonlegislative rule. 85

Although it has been rejected by most courts, the substantial impact test has been praised by several commentators. ${ }^{86}$ More important, it has been transplanted into proposed federal regulatory reform bills that would write the substantial impact test into the statute. 87 Therefore, an understanding of how the test has been applied by the courts, and of its advantages and shortcomings, is essential im evaluating the reform legislation.

Judges who have used the substantial impact test have stressed a number of factors in assessing the substantiality of a rule's impact. These factors relate both to the nature of the impact and the nature of the rule.

80. 5 U.S.C. $\S 553(\mathrm{~b})(\mathrm{A})$ exempts from notice and comment requirements "rules of agency organization, procedure or practice." See United States Dep't of Labor v. Kast Metals Corp., 744 F.2d 1145, 1153 (5th Cir. 1984); National Ass'n of Home Health Agencies v. Schweiker, 690 F.2d 932, $949-50$ (D.C. Cir. 1982), cert. denied, 459 U.S. 1205 (1983); Reynolds Metals Co. v. Rumsfeld, 564 F.2d 663, 669 (4th Cir. 1977), cert. denied, 435 U.S. 995 (1978); Pennsylvania v. United States, 361 F. Supp. 208, 220 (M.D. Pa.), affd per curiam, 414 U.S. 1017 (1973); National Motor Freight Traffic Ass'n. v. United States, 268 F. Supp., 90, 95 (D.D.C. 1967), aff'd per curiam, 393 U.S. 18 (1968).

81. 5 U.S.C. $\$ 553(\mathrm{~b})(B)$ exempts a rule from notice and comment requirements "when the agency for good cause finds (and incorporates the finding and a brief statement of reasons therefor in the rules issued) that notice and public procedure thereon are impracticable, unnecessary, or contrary to the public interest." See, e.g., Levesque v. Block, 723 F.2d 175, 184-85 (1st Cir. 1983). See generally Jordan, The Administrative Procedure Act's "Good Cause" Exemption, 36 AD. L. REV. 113 (1984).

82. See Energy Reserves Group, Inc. v. Department of Energy, 589 F.2d 1082, 1095 (Temp. Emer. Ct. App. 1978).

83. Sce Lewis v. Weinberger, 415 F. Supp. 652, 659 (D.N.M. 1976).

84. See, e.g., Heckler v. Commumity Health Servs. 104 S. Ct. 2218, 2224 n.12 (1984); Buccaneer Point Estates, Inc. v. United States, 729 F.2d 1297, 1299 (11th Cir. 1984); Anderson, Clayton \& Co. v. United States, 562 F.2d 972, 980-85 (5th Cir. 1977), cert. denied, 436 U.S. 944 (1978) (among factors in determining validity of retroactive legislative tax regulation are the strength of taxpayer's rehiance interest and the harshness of according retroactive effect).

85. See infra notes 206-07 and accompanying text.

86. See 2 K. DAv1S, supra note 7, at $\S 7.18$; Warren, supra note note 7 , at $386-93,397-98$; Koch, supra note 7, at 1058-71; Mayton, The Legislative Resolution of the Rulemaking versus Adjudication Problem in Agency Lawmaking, 1980 Duke L.J. 103, 122-29; Note, A Functional Approach, supra note 7 , at $443-46$.

87. See infra notes $182-204$ and accompanying text. 
In assessing the degree of impact, courts consider the degree to which the rule is pervasive in scope, ${ }^{88}$ whether it seems to have a definable, significant, and self-executing impact on people's lives or their legal or economic status, ${ }^{89}$ and whether it has a retroactive effect. 90

When considering factors related to the nature of the rule, courts are more likely to hold that a rule had substantial impact when it represents a significant change in the agency's position ${ }^{91}$ or when the rule is unusually controversial or complex. ${ }^{92}$ Furthermore, a court is likely to require notice and comment procedure if public participation and the creation of a detailed record would serve a useful purpose. Public input might be useful if judicial review is hikely and a better record is needed, the factual basis for the rule is dubious, or the agency lacks expertise in the subject matter and has never canvassed it in any public proceedings. ${ }^{93}$

A major shortcoming of the substantial impact test is that it has no solid foundation in the APA. The exemption from notice and cominent requirements for nonlegislative rules appears to have been written witl the legal effect test, not the substantial impact test, in mind. ${ }^{94}$ Further-

88. Brown Express, Inc. v. United States, 607 F.2d 695702 (Sth Cir. 1979) (discussing procedural exceptions); Chisholm v. FCC, 538 F.2d 349, 394 (D.C. Cir.) (Wright, J., dissenting), cert. denied, 429 U.S. 890 (1976); Pharmaceutical Mfrs. Ass'n. v. Finch, 307 F. Supp. 858, 864-66 (D. Del. 1970).

89. See Brown Express, Inc. v. United States, 607 F.2d 695, 702 (5th Cir. 1979); Eastern Kentucky Welfare Rights Org. v. Simon, 506 F.2d 1278, 1291-93 (D.C. Cir. 1974) (dissent), vacated on other grounds, 426 U.S. 26 (1976); Pickus v. United States Bd. of Parole, 507 F.2d 1107, 1112-13 (D.C. Cir. 1974); Lewis-Mota v. Secretary of Labor, 469 F.2d 478, 482 (2d Cir. 1972). The rule considered in the Eastern Kentucky case had a peculiarly significant impact on its victims because there were no legal means by which it could ever be challenged, either before the agency or in court. See Asimow, supra note 7, at 555-56. Additional examples of substantial impact are provided by cases considering the publication requireinent of APA $\S 552(a)(1)(D)$. See Anderson v. Butz, 550 F.2d 459, 462-63 (9th Cir. 1977); Lewis v. Weinberger, 415 F.Supp. 652, 659-60 (D.N.M. 1976).

90. See St. Francis Meniorial Hosp. v. Weinberger, 413 F. Supp. 323, 329-30 (N.D. Cal. 1976) (disallowing reimbursement of previously incurred debt).

91. See Brown Express, Inc. v. United States, 607 F.2d 695, 702-03 (5th Cir. 1979); Chisholm v. FCC, 538 F.2d 349, 394 (D.C. Cir.) (Wright, J., dissenting), cert. denied, 429 U.S. 890 (1970); Sannon v. United States, 460 F. Supp. 458, 466 (S.D. Fla. 1978); St. Francis Menorial Hosp. v. Weinberger, 413 F. Supp. 323, 329-30 (N.D. Cal. 1976); Pharmaceutical Mfrs. Ass'n v. Finıch, 307 F. Supp. 858, 864 (D. Del. 1970).

92. See American Bancorp. v. Board of Governors of the Fed. Reserve Sys., 509 F.2d 29, 39 (8th Cir. 1974); Sannon v. United States, 460 F. Supp. 458, 466 (S.D. Fla. 1975).

93. See Pharmaceutical Mfrs. Ass'n. v. Finch, 307 F. Supp. 858, 864-65 (D. Del. 1970).

94. See APA Legislative History, S. Doc. No. 248, 79th Cong., 2d Sess. 18 (S. Jud. Comm. print) (1946) [hereinafter cited as APA Legislative History] (interpretive rules subject to plenary judicial review while legislative rules involve a nuxinum of judicial discretion); S. Doc. No. 8, 77th Cong., 1st Sess. 26-27, 99-100 (1941) (Final Report of the Attorney General's Committec on Administrative Procedure) ("statements of policy" and "interpretations" rarely published, but "are not binding on those affected"). Cf. ATTORNEY GeNERAL's MANUAL ON THE APA, supra note 14, at 30 \& n.3 (noting that notice and comnient requirements apply ouly to substantive rules, which "have the force and effect of law"). 
more, the practical impact of a rule seems virtually irrelevant in determining whether an agency made new law or explained existing law. ${ }^{95}$ Finally, the test cannot be justified by asserting that fairness requires agencies to provide notice and comment before adopting important nonlegislative rules. ${ }^{96}$ After Vermont Yankee Nuclear Power Corp. v. Natural Resources Defense Council, Inc., ${ }^{97}$ courts cannot, in the interests of fairness, improved decisionmaking, or facilitation of judicial review, require agencies to go beyond the minimuin standards established in the APA when adopting rules. ${ }^{98}$ An agency must decide for itself whether additional procedures should be employed. ${ }^{99}$

In addition to its lack of theoretical support, the substantial impact test also fails as a judicially inanageable standard. Obviously, any litigated rule had a significant impact on someone; otherwise it would not be worth litigating. Whether that impact is "substantial" is a question to which no principled answer can be given, because it is impossible to quantify the variables that courts must address. As a result, judicial decisions under the substantial impact test seem ad hoc and unprincipledconsiderably more so than decisions under the legal effect test. ${ }^{100}$

Whether a particular rule has a substantial impact will depend upon impressions and imtuitive conclusions. For example, how substantial must the impact be-just palpable or devastating? ${ }^{101}$ How frequently

95. See Cabais v. Egger, 690 F.2d 234, 237-38 (D.C. Cir. 1982) (test has continuing vitality as one of several criteria for evaluating claims of exemption, but useless in distinguishing interpretive from legislative rules). Many legislative rules have little or no practical inpact, and many interpretive rules have significant practical impact. See American Postal Workers Union v.United States Postal Serv., 707 F.2d 548, 560 (D.C. Cir. 1983), cert. denied, 104 S. Ct. 1594 (1984). Indeed, rules made by agencies without delegated legislative power are "necessarily interpretive[,] regardless of their impact." Joseph v. United States Civil Serv. Comm'n, 554 F.2d 1140, 1154 n.26 (D.C. Cir. 1977).

96. But see Joseph v. United States Civil Serv. Conin'n., 554 F.2d 1140, 1154 n.26 (D.C. Cir. 1977) (courts should not give "binding effect" to interpretive rule, but perhaps "require soine sort of public participation in its issuance in the name of fairness").

97. 435 U.S. 519 (1978).

98. Id. at 546-47. See generally Stewart, Vermont Yankee and the Evolution of Administrative Procedure, 91 HARV. L. REv. 1804 (1978).

99. See Rivera v. Becerra, 714 F.2d 887, 890-91 (9th Cir. 1983) (rejecting the substantial impact test), cert. denied, 104 S. Ct. 1591 (1984); Cabais v. Egger, 690 F.2d 234, $237-38$ (D.C. Cir. 1982) (substantial impact test does not distinguish legislative from interpretive rules). But see Batterton v. Marshall, 648 F.2d 694, 708-10 (D.C. Cir. 1980) (asserting that substantial impact test survives Vermont Yankee); $2 \mathrm{~K}$. DAvis, supra note 7, at $\$ 7.19$ (challenging the notion that courts cannot require agencies to follow procedures not required by the APA).

100. No claim is made that decisions under the legal effect test are always predictable and principled. See supra notes 20-23 and accompanying text.

101. According to the House Judiciary Committec, which reconinended legislative adoption of the substantial impact test, the impact must be "palpable and significant" rather than "incidental or trivial." House Judiciary COMmitTeE, Regulatory Procedure ACt of 1982, H.R. ReP. No. 435, 97th Cong., 2d Sess. 61 (1982) [hereinafter cited as HOUSE REPORT]. 
must it be felt? To trigger public participation, must the affected class be the entire regulated group, or a subpart of that group? If the rule is beneficial to the regulated group, liow large a segment of the general public must be detrimentally affected to make the impact substantial? What percentage of the class must be negatively affected? ${ }^{102}$ And what type of interests must be affected-riglits, customs, expectations, or liopes? ${ }^{103}$ The courts have seldom, if ever, seriously addressed these questions.

Courts applymg the substantial impact test tried to decide wliether an opportumity to participate im a new rulemaking process might help protect the interests of affected members of the public or miglit assist the agency to improve the rule. Some, perhaps most, decisions holding that a rule had a substantial impact seem to liave been based on a calculation that the benefits of participation would outweigh the costs of additional procedure and of judicial invalidation of an existing rule. ${ }^{104}$ Unfortunately, few judges are equipped to make more than a wild guess about such matters.

The unprincipled, ad hoc character of tlie substantial impact test renders it nearly useless for predictive purposes. As a result, when formulating a nonlegislative rule that might have some appreciable mipact on someone, a well-counseled agency would always provide notice and comment. This would be cumbersome, costly, and quite useless in a great many cases. Vermont Yankee rightly disapproved judicial methodologies that would compel agencies to overproceduralize their processes. ${ }^{105}$ And as we sliall see, significant mcreases in the costs of adoptimg noulegislative rules are likely to diminish their flow. ${ }^{106}$

102. See HouSE REPORT, supra note 101, at 61 (must affect at least a majority of a regulated group); Note, supra note 31, at 526-529 (indeterminacy of what constitutes significant impact).

103. According to the House Judiciary Committee, a rule would have to affect "substantive rights or obligations," as opposed to "procedural rights or . . . mere interests." HousE REPORT, supra note 101, at 62 .

104. See, e.g., Stoddard Lumber Co. v. Marshall, 627 F.2d 984, 987 (9th Cir. 1980); Batterton v. Marshall, 648 F.2d 694, 704 (D.C. Cir. 1980); Chisholm v. FCC, 538 F.2d 349, 394 (D.C. Cir.) (Wright, J., dissenting), cert. denied, 429 U.S. 890 (1976); Eastern Kentucky Welfare Rights Org. v. Simon, 506 F.2d 1278, 1291-92 (D.C. Cir. 1974) (Wright, J., dissenting), vacated on other grounds, 426 U.S. 26 (1976); Pharmaceutical Mfrs. Ass'n. v. Fmch, 307 F. Supp. 858, 86466 (D. Del. 1970).

105. See Vermont Yankee Nuclear Power Corp. v. Natural Resources Defense Council, Inc., 435 U.S. 519, 546-47 (1978).

106. See infra notes 111-30 and accompanying text. Although the substantial impact test is not a defensible guide for the judiciary to use in distinguishing between legislative and nonlegislative rules or in imposing extra procedures in the interest of fairness, it remains helpful in guiding an agency decision to provide notice and comment procedure even if not required. See infra notes 20607 and accompanying text. 


\section{RECONSIDERING THE STATUTORY EXEMPTION FOR NON- LEGISLATIVE RULES}

After observing the judiciary's struggle with the legal effect and substantial impact tests, many observers are tempted to write a solution into administrative procedure statutes. Why not require that agencies provide notice and comment procedures before adopting most or even all nonlegislative rules? Indeed, both state and federal reform proposals would greatly increase the nuinber of nonlegislative rules that could be adopted only after pubhic participation. ${ }^{107}$ This section explores the effects on agency behavior of the enactinent of such legislation and attempts to test the hypothesis that the public would be better off if it were enacted. This test requires identification, measurement, and comparison of the costs and benefits of expanded public participation in the nonlegislative rulemaking process.

\section{A. Costs and Benefits of Requiring Pre-Adoption Procedures for Nonlegislative Rules.}

1. Benefit to the Public From Pre-Adoption Procedure. The rulemaking procedures of the APA have been widely acclaimed as a brilliant pohtical innovation. The notice and comment procedure, togetlier with hard-look ${ }^{108}$ judicial review, addresses our uneasiness with broad legislative delegations to administrative agencies and with the tenuous nature of the other legislative and judicial cliecks on agency behavior.

The APA notice and comment procedure infuses the rulemaking process with significant elements of openness, accountability, and legitimacy. Public participation promotes fundamental democratic values by enhancing the responsiveness of agencies to the interest groups affected by regulation. It opens the process to groups and individuals with discordant points of view who might otherwise not liave been heard during an agency's routine process of consultation with the public. In short, through advance notice and comment, every constituency has an opportunity to participate in a ineaningful manner in making the laws that will affect it.

The requirement tliat agencies invite and give consideration to public comments broadens an agency's perspective, which otlierwise might not extend beyond the views of the staff or the client groups with whom

107. See infra notes 132-204 and accompanying text. Unfortunately, these proposals will do little to solve the characterization problem, because they maintain a zone within which an agency can adopt rules without notice and comment. Patrolling the borders of this zone will be no less difficult than doing so under present law. See infra notes 156-59, 170-72, 184-203 and accompanying text.

108. See, e.g., Portland Cement Ass'n. v. Ruckelshaus, 486 F.2d 375, 394 (D.C. Cir. 1973). 
the staff regularly consults. An invitation to submit comments stimulates outsiders to furnish data and other imputs, providing a source of low-cost information to agency decisionmakers. A rule is hikely to be a better product if its drafters must consider seriously alternatives that they might have overlooked or take account of practical problems that otherwise would crop up only after a rule goes into effect. In addition, an agency may receive inore cooperation and less obstruction from regulated interests that have had a hand in shaping the rules within which they must function. ${ }^{109}$ Finally, by generating a record of public comment and agency response, the notice and comment system facilitates pre-enforcement hard-look judicial review, an important check on factually unsupported or arbitrary regulation.

In some respects, the advantages of notice and comment rulemaking apply equally to legislative and nonlegislative rulemaking. Members of interest groups affected by nonlegislative rules would certainly utilize and probably benefit from an advance opportunity to influence an agency concerning the desirability and the content of such rules. ${ }^{110}$ Pre-adoption notice and comment would be a useful supplement to the channels of influence already available, such as informal consultation with the staff and post-adoption critiques and modification petitions.

Realistically, however, few nonlegislative rules have the practical significance of the great bulk of legislative rules. The vast majority of nonlegislative rules are insignificant, of primarily internal innportance to the agency, or indisputably valid. An invitation to comment in such cases would produce no response or, at most, a trivial pro forma response from people paid to keep track of agency activity.

2. Costs of Rulemaking Procedure. Although notice and comment rulemaking procedures have a great many benefits, they are not cost-free. Indeed, the rulemaking process can be both ponderous and costly.111 To produce any new rule, whether legislative or nonlegislative, an agency must incur the substantial bureaucratic costs of overcoming inertia. The internal process includes research, resolution of staff con-

109. See E. BARDACH \& R. KAGAN, supra note 34, at 178-81. But see Achterman \& Fairfax, The Public Participation Requirements of the Federal Land Policy \& Management Act, 21 ARIz. L. REV. 501, 508 (1979) ("there is no reason to assume that the opportunity to participate leads to more readily accepted decisions. Public involvement programs . . . may easily mobilize dissent").

110. Under present practice, agencies frequently invite public comments before making important nonlegislative rules. Often the public participation is enthusiastic. For example, there is extensive participation in the making of IRS interpretive rules and FCC policy statements.

111. See, e.g., E. BARDACh \& R. KAGAN, supra note 34, at 193-95 (1982); Schuck, When the Exception Becomes the Rule, 1984 DUKE L.J. 163, 194-96; Cooper, Regulatory Reform? 35 FooD DRUG. Cosm. L.J. 183, 199-202 (1980). 
flicts, informal consultation with interested outsiders, agreement upon precise language, consensus-building, and multilevel review. The financial and psychological costs of forging consensus within an agency on the contents of a new rule may be quite substantial. ${ }^{112}$

If public participation is legally required, or if the agency chooses voluntarily to provide it, the agency must then publish a notice of its proposal in the Federal Register and mail notice to persons known to be interested. The public process continues through the receipt of comments (typically with time extensions to accommodate commentators who wish to perform studies), public hearings (which are not required but often provided), staff analysis of the comments, preparation of a reasoned statement of basis and purpose, and prepublication in the Federal Register. ${ }^{113}$ The final act takes place in the courts when the rule is subjected to pre-enforcement judicial review.

By general consensus, it usually takes between six and twelve months to push an uncontroversial rule through notice and comment procedure unless unusual steps are taken to accelerate the process. If a rule is controversial, or if an outsider or factions within the agency have an interest in delaying its adoption, a much longer delay is likely. During the rulemaking period, regulated entities remam uncertain about the ultimate course of regulation and thus are inhibited from making plans. Moreover, during this period, the regulatory program cannot operate with full effectiveness. As a result, whatever benefits are supposed to accrue from a particular rule are deferred.

3. An Economic Model of Bureaucratic Choice. Agency decisionmakers, like all rational beings, seek to function efficiently by maximizing utility-both their own and that of the regulatory program for which they are responsible. Given a fixed budget and many competing uses of available resources, efficient operation involves a constant weighing of the net marginal costs and benefits of a proposed course of action. Thus, in order to undertake a new legislative or nonlegislative rulemaking project, an agency must conclude that the net marginal benefits to the regulatory program or to the agency from adopting an incremental rule outweigl the net marginal bureaucratic costs of adopting it. ${ }^{114}$

112. See A. Downs, InSIDE Bureaucracy 178-82; Diver, supra note 30, at 73, 75 (discussing social costs of rulemaking). Of course, an agency's costs include not only expenditures on staff and other out-of-pocket expenses but also the foregone opportunities to produce other valuable outputs.

113. Proposed regulatory reform laws would add additional steps. For example, they frequently require more explanatory material in the notice, public hearings, cross examination, regulatory analyses, or strict deadlines. See, e.g., S. 1080, 97th Cong. 1st Sess. §§ 2-3.

114. See A. DownS, supra note 112, at 195-96; H. Simon, ADMINISTRATIVE BehaVior 122, 172-97 (3d ed. 1976); B. Mrtnick, The Political ECONOMY of Regulation 132-38 (1980); 
In other words, there must exist a supply curve of bureaucratic outputs; increasing the net costs of producing any particular output will usually diminish the supply of that particular output. Given an increase in cost of producing one type of product, an agency might decide to produce the same number of umits and cut soine other output or program. Alternatively the agency might rationally decide to use its limited resources to produce soine other category of output or take advantage of soine other opportunity. More typically, however, the agency would decide to produce fewer units of the nore costly output while keeping the proportion of the budget allocated to it the same. ${ }^{115}$

While the slope of the supply curve will vary froin one agency to another, it seems likely that the supply of nonlegislative rules is quite sensitive to increases in bureaucratic production costs. Interpretive rules and policy statements are different fronı other bureaucratic outputs in one critical respect: a regulatory program can function without them. Legislative rules are often necessary to set a regulatory program in inotion. However, the purpose of nonlegislative rules is to diminish uncertainty. For the niost part, the costs of uncertainty are borne by nieinbers of the public, not by the agency. For that reason, uncertainty is an externality that agency utility-niaximizers need not take nito account.116 Thus an agency inay well choose to inuddle through without producing any guidance docuinents, or it may choose to transmit any necessary guidance to its staff through informal intra-agency menioranda, hallway conversations, or other subformal communications. It inay feel hittle or no compulsion to issue a steady flow of publicly available nonlegislative rules. ${ }^{117}$

Of course, a new interpretation or pohicy may improve administration or raise the level of compliance, but these are long-term considerations; in the short term, an agency can get along without thein. Given a choice of how to deploy scarce internal resources, an agency might de-

Diver, supra note 30, at 72-76; Gifford, supra note 35, at 125-35; Gifford, supra note 28, at 18-19; Rabin, Agency Criminal Referrals in the Federal System: An Empirical Study of Prosecutorial Discretion, 24 STAN. L. REV. 1036, 1045-52 (1972).

115. Cf. Scanlon \& Rogowsky, Back-door Rulemaking: $A$ View from the CPSC, REg. July-Aug. 1984 , at $27-28$ (substitution of adjudication for costly rulemaking).

116. See Diver, supra note 30, at 102-03 (confusion and evasion generated by regulatory vagueness burdens public far more than regulator).

117. Cf. American Fed'n of Gov't Employees v. O'Connor, 747 F.2d 748 (D.C. Cir. 1984) American Federation held that advisory opimions of the special counsel of the Merit Systeins Protection Board concerning applications of the Hatch Act are not ripe for pre-enforcement judicial review. Id. at 752-57. The court stated that immediate review of the opinions would discourage their issuance in higlt of the severe budgetary constraints under whicl the special counsel operates. Id. at 754. Dissenting, Judge Mikva contended that judicial review would not chill the rulings process since issuance of rulings is the most efficient way to prevent disputes. Id. at 760 . 
cide that it is more important to issue legislative rules, conclude pending adjudications, investigate misconduct, answer urgent requests for advice, or prepare congressional testimony. Nonlegislative rules can usually be deferred until additional resources become available. Thus they must often be losers in the unending imternal struggle for resources.

Moreover, there may be staff opposition to a proposed nonlegislative rule: some will argue that it outlines possible paths of evasion, that it is over- or under-mclusive, that it will mduce undue rigidity, or that it will strip staff meinbers of their influence and power by making public the secret law they have apphed. ${ }^{118}$ Thus, to personnel who must decide whether to adopt a new nonlegislative rule, the net regulatory benefit may seem neghigible and the net costs, exclusive of the costs of public procedure, may seem substantial.

A decision to put off rulemaking is much more likely to occur if the law requires additional steps, like notice and comment procedure, to be taken before the rule can be adopted. These procedures divert busy people from tasks that may seem to have a higher priority and impose significant internal communication and other bureaucratic costs. As a result, requirements of notice and comment will shift the supply curve for nonlegislative rules to the left; given a constant demand for this particular bureaucratic output, fewer will be produced. To express the same thought another way, the level of utility that an agency requires of an incremental nonlegislative rule at the margin inust rise if the internal costs of adoptimg it are mcreased. Thus, requiring agencies to conduct notice and comment procedure surely would discourage the adoption of at least some marginal nonlegislative rules.

There is some scattered empirical evidence to support the proposition that the supply of nonlegislative rules is quite sensitive to the bureaucratic costs of adoptimg them. First, this theme emerged again and again in the course of interviews that the author conducted in many agencies about the nonlegislative rulemaking process. ${ }^{119}$ Although such statements should be discounted somewhat as the predictable responses of agency staff members who do not wish to be bothered with any new controls, the author is convinced that the problem is very real.

118. See Diver, supra note 30, at $94-95$ (discussing the withdrawal by INS of proposed policy statement because of internal opposition to constraining discretion).

119. This interviewing provided the empirical base for Asimow, supra note 7. This concern was expressed in interviews with personnel at OSHA, IRS, SEC, FDA, FTC, FCC, and the Wage and Hour Division of the Department of Labor (Inemoranda of interviews are on file with the author). See also letters from HEW (Feb. 11, 1977) and Treasury (Aug. 12, 1976) to Robert Anthony, Chair of the Administrative Conference (additional procedural steps will discourage nonlegislative rulennaking). 
For example, between 1974 and 1984, the number of published Internal Revenue Service (IRS) revenue rulings declined steadily from 626 to 179 per year. ${ }^{120}$ There are several reasons for this precipitous decline. Both the IRS and the Treasury Department (which reviews all publislied rulings) recognized that the process of putting out rulings is costly and should be reserved for significant interpretations. ${ }^{121}$ In addition, the IRS and the Treasury Department instituted more careful review of proposed new rulings. In the absence of prodding by management to cut the backlog, the review commitment led to bottlenecks and delays as hundreds of rulings piled up on tlie desks of very busy people. Both the delays and the nit-picking reviews discouraged ruling writers who sought otler, more rewarding assignments. Finally, the personnel who produce or review revenue rulings have frequently been diverted to other, more urgent tasks. Both the IRS and the Treasury Department have been deluged witli tlie tasks of preparing testimony and promulgating regulations to iniplement the constant flow of new tax legislation. In addition, substantial resources have been diverted to discharging the responsibility of the IRS to samitize and publicize its private letter rulings. ${ }^{122}$

The IRS experience illustrates that the output of nonlegislative rules responds to insertion of new procedural liurdles, sucli as additional reviews, into the production process. It also shows that an agency can easily redeploy its resources from producing nonlegislative rules in favor of higher priority tasks. Because the IRS can function quite well without producing any revenue rulings at all-it can leave the public in the dark or it can respond to requests for advice with private letter rulings-the public ruling process is a certain loser in the struggle for resources.

In California, judicial and legislative innovations liave provided evidence about the effects of increasing the costs of issuing nonlegislative rules. ${ }^{123}$ In 1978, the California Supreme Court lield in Armistead v. State Personnel Board, 124 that nonlegislative rules could not be adopted without prior notice and comment. Most agencies largely ignored the decision. A few tried to coniply but encountered considerable difficulty in deciding which rules were covered. Soine agencies apparently decided

120. See 1974-1 \& 2 C.B. (reporting 626 decisions); 1984-1 \& 2 C.B. (reporting 179 decisions).

121. The material on IRS and Treasury decisionmaking is based on interviews with present and former IRS and Treasury personnel. Copies of these interviews are on file with the author.

122. See I.R.C. $\S 6110$ (a) (1982) (requiring the Secretary to open any written determination to public inspection).

123. The inaterial on Califormia rulennaking is drawn from interviews with personnel in agencies, the Attorney General's office, and present and former staff ineinbers of the Office of Administrative Law (copies of these interviews are on file with the author).

124. 22 Cal. 3d 198, 201-03, 583 P.2d 744, 745-47, 149 Cal. Rptr. 1, 2-3 (1978). 
not to adopt revisions to staff manuals or other nonlegislative rules because of the costs of complymg with Armistead.

In 1982 and 1983, the California legislature explicitly amended its APA to require notice and comment before the adoption of both legislative and nonlegislative rules. ${ }^{125}$ The statute also required approval of the rules by the Office of Administrative Law (OAL), ${ }^{126}$ and empowered the OAL to issue determinations that nonlegislative rules had been improperly adopted. ${ }^{127}$ An exception was made for tax agencies, which had found it unduly expensive to comply with Armistead. ${ }^{128}$

This legislation has produced a great deal of confusion. Many agencies have ignored the requirements, apparently hoping that failure to comply will have no negative consequences. Others have complied with the requirements but issued fewer nonlegislative rules. The OAL is uncertain how to implement the statute and how its limited resources can be stretched to cover the new burden of supervising the nonlegislative rulemaking process. ${ }^{129}$

No final conclusions can yet be drawn from the California experience. Agencies and the OAL may accommodate themselves to the new law and produce a steady flow of rules adopted after appropriate public involvement. So far, however, the results are largely negative.

4. Balancing the Costs and Benefits. Nonlegislative rules are enormously important to members of the public who must hive with regulation. Any significant diminution in the flow of interpretive rules or policy statements disserves the public imterest.

Interpretive rules, for example, serve a number of vital purposes. Unless an interpretation is embodied im a legislative rule, a nonlegislative imterpretation is superior to other techniques. Interpretive rules are more accessible, more rehable, and, because of their generalized form, much more useful than interpretation supphed through formal or informal adjudication or advice letters.

For similar reasons, the public has an important stake in encouraging an agency to structure its discretionary powers through the adoption of nonlegislative policy statements. A published policy statement is

125. Cal. Gov't. Code $\S 11,347.5$ (West Supp. 1985).

126. See id. at $\S 11,349.1$. For an excellent analysis of the unique powers of the California Office of Administrative Law, see Cohen, Regulatory Reform: Assessing the California Plan, 1983 DUKE L.J. 231.

127. See Cal. Gov’t. Code at $\S 11,347.5$.

128. Id. at $\S 11,342(\mathrm{~b})$.

129. Letter from Director of Office of Administrative Law to State Regulatory Agencies, May 11,1983 . For example, requests have been made that the office determine what portion of hundreds of volumes of staff manuals come under the notice and comment requirements of the law. 
much more useful than the same material tucked admidst the trivia in a staff manual, embedded in particularized decisions in formal or informal adjudications, or simply derived from the practices of the staff.

Given the importance of nonlegislative rules, should full-fledged notice and comment procedure be required before they are adopted? In 1946, the drafters of the APA concluded that the benefits of mandatory public procedure were outweighed by the issuance of fewer rules and by reduced effectiveness, increased cost, and undue delay. ${ }^{130}$

This article concludes that their call was close but right. ${ }^{131}$ Mandatory pre-adoption procedure would be a significant disincentive to nonlegislative ruleinaking. The public would lose inore than it would gain. The loss of a large quantity of relatively umimportant nonlegislative inaterial outweighs the benefits of providing a relatively small nuniber of people additional opportunities to influence the content of a relatively sinall number of important rules.

Many proponents of regnlatory reform disagree with this conclusion. The next section analyzes these reform proposals and concludes that the post-adoption proposal of the Admimstrative Conference is a preferable solution.

130. See Guardian Fed. Sav. \& Loan Ass'n v. FSLIC, 589 F.2d 658, 662 (D.C. Cir. 1978) (APA exceptions designed to "accommodate situations where the policies promoted by public participation in rulemaking are outweigled by the countervailing considerations of effectiveness, efficiency, expedition and reduction in expense").

Concern that mandatory procedure would discourage nonlegislative rulemaking was the first of several reasons for the exemption. See APA Legislative History, supra note 94, at 18. The Judiciary Committee staff wrote:

First, it is desired to encourage the making of sucli rules. Secondly, those types of rules vary so greatly in their contents and the occasion for their issuance that it seems wise to leave the matter of notice and public procedures to the discretion of the agencies concerned. Thirdly, the provision for petitions contained in subsection (c) affords an opportunity for private parties to secure a reconsideration of sucl rules when issued. Anotlier reason, whicl might be added, is that "interpretative" rules-as merely imterpretations of statutory provisions-are subject to plenary judicial review, whereas "substantive" rules imvolve a maximum of administrative discretion.

131. For earlier statements of reservations about expanding the scope of public participation in the adoption of nonlegislative rules, see Auerbacl, Administrative Rulemaking in Minnesota, 63 Minn. L. Rev. 151, 158-60 (1979); Administrative Procedure Act: Hearings Before the Subcomm. on Administrative Practice and Procedure of the Senate Comm. on the JudiciaRY, 89th Cong., Ist Sess. 138, 150, 174 (1965) (statement of Kenneth C. Davis). For discussion of the adverse effects of a poorly conceived expansion of public participation, see Acliterman \& Fairfax, supra note 109. 


\section{State and Federal Reform Proposals}

\section{A. Nonlegislative Rules and the 1981 Model State Administrative Procedure Act.}

1. Provisions of the Revised Act. The original Model State APA, which was first approved in 1946 and revised in 1961,132 contained no special provision for nonlegislative rules. The Act's broad definition of "rule" and coinprehensive provisions for notice and comment ${ }^{133}$ appeared to cover both legislative and nonlegislative rules. ${ }^{134}$

However, the Act's requirement of notice and comment for nonlegislative rules was implicit, not clear-cut, and could be ignored on a variety of pretexts. ${ }^{135}$ As a result, state agencies generally adopted interpretations and pohicy stateinents without any advance procedures and were seldoin corrected by courts. ${ }^{136}$ In a minority of states, however, court decisions invalidated nonlegislative rules adopted without inviting public comment or filed without following required procedures. ${ }^{137}$

In 1981, the National Conference of Commissioners on Uniform

132. See Model State Administrative Procedure Act, 14 U.L.A. 357, 359 (1980).

133. 1961 MODEL ACT, supra note 2 , at $\S 1(7)$ defines "rule" as "each agency statement of general applicability that implements, interprets, or proscribes law or policy .... The term in cludes the amendment or repeal of a prior rule but does not include . . . (C) intra-agency memoranda." Section 3 of the Act provides for notice and comment rulemaking "[p]rior to the adoption, amendment or repeal of any rule. ..."

134. See F. COOPER, State Administrative Law 185-87 (1965).

135. For example, the definition of "rule" could be understood to refer only to legislative rules, or nonlegislative rules could be classified as exempt "intra-agency memoranda." See also Frohnmayer, The Oregon Administrative Procedure Act: An Essay on State Administrative Rulemaking Procedure Reform, 58 OR. L. REv. 411, $428-39$ (1980) (discussing the meaning of "rule" and exceptions to the definition under the Oregon APA).

136. 1981 MODEL ACT, supra note 10, at § 3-109 comment.

137. California courts were particularly active. See Armistead v. State Persounel Bd., 22 Cal. 3d 198, 201-03, 583 P.2d 744, 745-47, 149 Cal. Rptr. 1, 2-3 (1978) (interpretive rules buried in staff manual invalid for want of prior notice and comment). See also Goleta Valley Community Hosp. v. State Dep't. of Health Serv., 149 Cal. App. 3d 1124, 197 Cal. Rptr. 294 (1983) (procedurally faulty interpretation held invalid); Ligon v. State Personnel Bd., 123 Cal. App. 3d 583, 587.88, 176 Cal. Rptr. 717, 719 (1981) (where APA not complied with, court refuses to give any weight to agency policy even as administrative interpretation). The holding in Armistead was codified at Cal. Gov't. Code $\S 11347.5$ (West Supp. 1985), requiring agencies to provide notice and comment before adopting any "guideline, criterion, bulletin, inanual, instruction, order, standard of general application, or other rule . . . " See supra notes 124-29 and accompanying text.

For cases from other states, see Cheshire Convalescent Center Inc. v. Commission on Hospitals and Health Care, 386 A.2d 264, 274 (Conn. C.P. 1977) (guidelimes for nursing home construction); District of Columbia v. Grecn, 310 A.2d 848, 854 (D.C. Ct. App. 1973) (interpretive rule concerning property tax); McKee v. Likens, 261 N.W.2d 566, $577-78$ (Minn. 1977) (taxpayer may sue to enjoin use of public funds under policy adopted without APA compliance); State v. Van Wie, 382 A.2d 372, $374-75$ (N.H. 1978) (filing of manual on administering breathalyzer tests substantially complied with APA filing requirements); Schoolway Transp. Co. v. Division of Motor Vehicles, 72 Wis. 2d 223, 232-37, 240 N.W.2d 403, 408-10 (1976). 
State Laws proposed a new Model State APA. ${ }^{138}$ In addition to notice ${ }^{139}$ and written comment, ${ }^{140}$ the new Act's rulemaking procedures also require the issuance of a concise explanatory statement ${ }^{141}$ and the maintenance of a rulemaking record. ${ }^{142}$ Furthermore, the new Model Act goes beyond other administrative procedure statutes to require, under certaim circumstances, oral hearings ${ }^{143}$ and the preparation of a detailed costbenefit analysis. ${ }^{144}$ If the process is not completed within a 180 -day period, it must begin anew. 145

Although the Act exempts nonlegislative rules from certain rulemaking procedures, the exemptions are narrowly drafted. For example, an agency may dispense with notice and comment ${ }^{146}$ "in the adoption of a rule that only defines the meaning of a statute or other provision of law or precedent if the agency does not possess delegated authority to bind the courts to any extent with its definition." 147 If an agency chooses to omit notice and comment, the published rule must include a statement to that effect, 148 and a reviewing court is instructed to "determine wholly de novo the validity" of the rule. 149

The exception for policy statements is equally narrow. ${ }^{150}$ An agency need not employ notice and comment procedures before adopting a rule that establishes "criteria or guidelines" to be used by the staff. ${ }^{151}$ However, the exception covers only criteria or guidelines relating to "performing audits, investigations, or imspections, settling commercial disputes, negotiating commercial arrangements, or in the defense, prose-

138. See 1981 MOdEL ACr, supra note 10.

139. See id. at $\S 3-103$.

140. See id. at § 3-104(a).

141. See id. at $\S 3-110$.

142. See id. at $\S 3-112$.

143. See id. at $\S 3-104(\mathrm{~b})$.

144. See id. at $\S 3-105$.

145. See id. at $\S 3-106$.

146. The Act does not permit the agency to dispense with publishing a concise explanatory statement, maintaining a rulemaking record, filing the rule with the secretary of state, or allowing a 30-day pre-effective period. See id. at $\S \S 3-110(a), 3-112,3-114,3-115$. These requirements alone will invalidate many rules. See, e.g., Sturman v. Ingraham, 383 N.Y.S.2d 60, 61 (App. Div. 1976) ("program" giving criteria for hospital construction not filed with state cannot be apphed).

147. 1981 MODEL ACr, supra note 10, at § 3-109(a) (emphasis added).

148. Id.

149. Id. at $\S 3-109(\mathrm{~b})$.

150. The new Act also exempts from required rulemaking procedure "a rule concerning only the internal management of an agency which does not directly and substantially affect the procedural or substantive rights or duties of any segment of the public[.]" Id. at \$ 3-116(1). It would seem that this exemption would cover only rules of strictly interual impact. See 1961 ModeL ACr, supra note 2, at § 1(7); Bonfield, The Iowa Administrative Procedure Act: Background, Construction, Applicability, Public Access to Agency Law, the Rulemaking Process, 60 IowA L. REv. 731, 833-34 (1975).

151. 1981 MODEL ACT, supra note 10, at $\S 3-116(2)$. 
cution or settlement of cases."152 Finally, the exception applies only "if disclosure of the criteria or guidelines would: (i) enable law violators to avoid detection; (ii) facilitate disregard of requirements imposed by law; or (iii) give a clearly improper advantage to persons who are in an adverse position to the state."153

The commissioners were clearly impressed by the need for pre-adoption procedures for nonlegislative rules and by the fact that many state agencies had ignored the requirements of prior law. ${ }^{154}$ In addition, they were uudoubtedly influenced by federal cases spelling out the substantial impact doctrine. ${ }^{155}$

\section{Analysis of the Revised Model Act.}

a. The delegated power criterion. Under section 3-109(a), whether an agency can adopt an interpretive rule without pre-adoption procedure turns upoil a construction of the agency's rulemaking power. This proposal has the striking advantage of solving the nagging definitional problems: If an agency has delegated rulemaking power, it must employ notice and comment procedure. Unfortunately, however, in solving one problem, the draftsmen of the 1981 Act have saddled agencies and courts with a new and possibly even 111ore onerous burden: construction of the scope of delegated rulemaking power.

Many regulatory statutes contain a general rulemaking power, such as a provision allowing an agency to adopt such rules and regulations as are required to implement the statute. This language might or might not be construed to provide an agency with delegated power to adopt a particular mterpretation. Under the influence of some modern federal cases, ${ }^{156}$ a state court could easily decide that a general rulemaking provision of this type provides a11 agency with the power to adopt binding legislative rules. ${ }^{157}$ On the other hand, a state court could also construe a

152. Id.

153. Id.

154. The Commissioners "bracketed" section 3-109 (the grudging exception for interpretive rules), so that a state can justifably omit the provision. See id. at \$ 3-109 comment. Similarly, the Comment to section 3-116, the narrow exception for policy statements, suggests that states should consider an additional provision requiring advance notice and comment procedure "to the extent it is practicable." Id. at $\$ 3-116$ comment.

155. See supra notes 78-106 and accompanying text. The Comment to section 3-109 refers to the substantial impact of interpretive rules as one justification for entirely omitting any exception to the procedural requirements. See 1981 MODEL ACT, supra note 10, at § 3-109 comment.

156. See, e.g., National Nutritional Foods Ass'n. v. Wemberger, 512 F.2d 688, 695-97 (2d Cir.), cert. denied, 423 U.S. 827 (1975); National Petroleum Refiners Ass'n v. FTC, 482 F.2d 672, 697-98 (D.C. Cir. 1973), cert. denied, 415 U.S. 951 (1974). See also Chrysler Corp. v. Brown, 441 U.S. 281, 303-12 (1979) (search for inexplicit sources of delegated legislative power).

157. See, e.g., Megdal v. Oregon State Bd. of Dental Examiners, 288 Ore. 293, 320-21, 605 P.2d 273, 287 (1979) (board must adopt legislative rules under its general rulemaking power). 
general rulemaking power to permit an agency to adopt only procedural or nonlegislative rules. ${ }^{158}$ In all likelihood, there will be no judicial decisions that clarify the scope of an agency's rulemaking power.

Section 3-109(a) seems seriously misdirected. Why should a procedural distimction be drawn between agencies that do and those that do not have legislative power to adopt their interpretations? Why should agencies be forced to speculate about whether they have delegated power to adopt rules even though they do not wish to use the power? Why should notice and comment procedures be required before adoption of a rule that has a trivial impact and is purely nonlegislative? ${ }^{159}$ Why should courts be compelled to grapple with the difficult and utterly irrelevant issue of the scope of a general rulemaking power when the agency disclaims its use?

b. The elimination of deference. Section 3-109(b) instructs a court to "determine wholly de novo the validity of a rule" adopted without notice and comment procedures. The effect of this provision is to preclude a court from deferring to many interpretive rules. ${ }^{160}$ It is similar to the proposed Bumpers Amendment to the federal APA, ${ }^{161}$ which has

158. This issue is generally obscured in state administrative law decisions. But see Morgan v. Stimson Lumber Co., 607 P.2d 150, 154 (Ore. 1980); State ex rel. Comm'r of Ins. v. North Carolina Rate Bureau, 269 S.E.2d 547, 568-69 (N.C. 1980).

159. Section 3-108 of the 1981 Act contains a "good cause" exemption similar to that in APA $\S 553$ (b) (B). It permits immediate adoption of a rule when notice and comment procedure would be "unnecessary, impractical, or contrary to the public interest." See 1981 MoDEL ACT, supra note 10, at $\$ 3-108(a)$. The agency has the burden of estabhishing entitlement to the exemption. Id. at $\S 3$ 108(b). Under this exemption, agencies can dispense with superfluons procedure before adopting trivial nonlegislative rules. However, the courts have been strict in applying the corresponding provision of the federal APA. See, e.g., Levesque v. Block, 723 F.2d 175, 184 (1st Cir. 1983) (good cause exception "is narrowly construed"). See generally Jordan, supra note 81, at 129-35.

In a comment to section 3-108, the Commissioners express the hope that the "shifted burden of persuasion" required by section 3-108(b) will "make abuse of this exemptive provision infrequent because the consequences facing an agency if it guesses incorrectly are too serious to justify the risk of using the exemption in close or imclear cases." 1981 MODEL ACT, supra note 10, at $\S 3-108$ comment. Consequently, an agency in doubt about whether public procedure is "unnecessary" must err on the side of providing for it.

160. "A reviewing court shall determine wholly de novo the validity of a rule within the scope of subsection (a) that is adopted without complying with the provisious of Sections 3-103 through 3108." 1981 MODEL ACT, supra note 10, at $§ 3-109$ (b).

161. The Bunpers Amendment is included as section 5 of S.1080, which was unenacted regulatory reform legislation. Section 5 was intended to amend 5 U.S.C. $\S 706$ ( $\$ 10(e)$ of the APA). S.1080, 97th Cong. 1st Sess. $§ 5,128$ CoNG. REc. S2717 (daily ed. Mar. 24, 1982). See generally Levin, Review of "Jurisdictional" Issues under the Bumpers Amendment, 1983 DukE L.J. 355; O'Reilly, Deference Makes a Difference: A Study of Impacts of the Bumpers Judicial Review Amendment, 49 U. CINN. L. REv. 739 (1980). In the version of the Bumpers Amendment embodied in S. 1080 , courts would be required to decide questions of law "imdependently." S. 1080, 97th Cong., 1st Sess. $\S 5,128$ CoNG. REC. $\$ 2717$ (daily ed. Mar. 24, 1982) (amending 5 U.S.C. $§ 706(a)$ ). They could not rely upon "any presumption in favor of or agamst agency action." Id. at S2718 (amending 
been opposed both by scholars ${ }^{162}$ and by the Administrative Conference of the United States. ${ }^{163}$

There are several reasons why state courts should be permitted to establish rebuttable presumptions in favor of agency legal interpretations, especially those embodied in nonlegislative rules. ${ }^{164}$ In nany situations, deference to administrative legal interpretations is appropriate beyond any reasonable doubt. For exaniple, suppose an agency announces an interpretation of language contamed in a previously adopted legislative rule relating to a technical provision in the underlying statute. The staff justifiably claims expertise in the particular adninistrative problem. The interpretation appears carefully reasoned and does not involve a sudden reversal of prior policy. In such a case, judicial deference to the interpretation is not only justified, it is inevitable.

Furthermore, de novo review of issues of law encourages litigants to seek judicial review of interpretations with which they disagree. With the presumption in force, a party will not appeal unless it can develop persuasive argunients that an imterpretation is invalid.

Moreover, deference is an essential element of the relationship between agencies and reviewing courts. It expresses the sanie coninion sense notions of comparative qualifications as the substantial evidence test, ${ }^{165}$ the classification of niost nixed questions of law and fact as questions of fact, ${ }^{166}$ and the narrow scope of review accorded to courts that review agency discretionary actions or determinations of policy. ${ }^{167}$ Legislatures intended to let agencies make these decisions; they did not intend that the courts would frequently interpose their own judgnient. ${ }^{168}$

5 U.S.C. $\$ 706(c))$. Instead, "the court shall give the agency interpretation such weight as it warrants, taking into account the discretionary authority provided to the agency by law." Id.

162. See, e.g., McGowan, Congress, Court and Control of Delegated Power, 77 Colum. L. Rev. 1119, 1162-68 (1977); Pierce \& Shapiro, Political and Judicial Review of Agency Action, 59 Tex. L. REv. 1175, 1189-95 (1981); Woodward \& Levin, In Defense of Deference: Judicial Review of Agency Action, 31 AD. L. REv. 329, 329-44 (1979). But see Kennedy, The Bumpers Amendment: Regulating the Regulators, 67 A.B.A. J. 1639, 1641 (1981) (arguing that Buinpers Amendment is necessary to assure that agencies comply with congressional intent).

163. See 1 C.F.R. $\S 305.79-6$ (1984) (recommending that the Bumpers Amendment not bc enacted).

164. State courts frequently defer to agency interpretations of ambiguous statutes or rules. See 1961 Model ACT, supra note 2, at 495-96 (1980), 220-21 (1984 Supp.); F. CoOPER, supra note 134, at 265 n.100, 266, 267-68. But see Brodie \& Linde, State Court Review of Administrative Action: Prescribing the Scope of Review, 1977 ARIz. ST. L.J. 537, 546 ("state courts probably take for granted that the correct interpretation and application of terms used in the statute, rulc, standard, or concept fall within their province").

165. See e.g., Universal Camera Corp. v. NLRB, 340 U.S. 474 (1951).

166. See, e.g., NLRB v. Hearst Publications, Inc., 322 U.S. 111 (1944).

167. See e.g., Citizens to Preserve Overton Park, Inc. v. Volpe, 401 U.S. 402 (1971).

168. See Chevron, Inc. v. National Resources Defense Council, 104 S. Ct. 2778, 2782-83 (1984) (court must defer to reasonable interpretation when Congress implicitly delegates to agency); 
Nevertheless, the 1981 Model Act precludes a court from giving deference where an agency properly adopts an interpretation without preadoption procedure, regardless of the insignificance of the interpretation, its obvious correctness, or the irrelevance of pre-adoption procedure. ${ }^{169}$

c. The policy statement exemption. Section 3-116(2) of the Model Act provides that agencies can adopt policy statements witlout notice and comment if disclosure of agency guidelines and criteria would obstruct law enforcement or give an improper advantage to persons adverse to the state. ${ }^{170}$ However, courts cannot easily determine the effects of disclosure. Publicity of tax audit guidelines would obviously "facihitate disregard of requirements imposed by law," "171 but it is unlikely that other typical pohicy statements could so easily ineet these standards. One can imagine lengthy and expensive trials devoted to resolving whether someone with knowledge of agency guidelines might avoid detection or obtain a clearly improper advantage in dealing with the state. As a result, a vast quantity of guidelines, priority settings, staff manuals and bulletins, and similar discretion-himiting material could not be issued without prior public participation. ${ }^{172}$

Furthernore, during the transition period, inost agencies will not yet have provided for public involvement before routinely issuing the sort of material now contained in news releases, letters, administrative manuals, or staff bulletins. Because agency action based on an invahdly adopted policy statement is of dubious validity, ${ }^{173}$ section 3-116(2) inay

Coffman, Judicial Review of Administrative Interpretation of Statutes, 6 W. NEW ENG. L. REV. 1, 33 (1983); Monaghan, Marbury and the Administrative State, 83 CoLUM. L. REv. 1, 33 (1983) ("the judicial duty is to ensure that the administrative agency stays within the zone of discretion committed to it by its organic act"). But see Byse, Scope of Judicial Review in Informal Rulemaking, 33 AD. L. REV. 183, 190-93 (1981) (it is inconsistent with our basic political and governmental theory for courts to hold that the agency's interpretation will be controlling so long as that niterpretation is reasonable).

169. Under the "good cause" exemption of section 3-108(a), pre-adoption procedure could be omitted in cases of obviously trivial rules, and a court would not be required to review the rule de novo. However, this provision is narrowly drawn and an agency could not rely upon it in doubtful cases. See supra note 159.

170. 1981 MODEL ACT, supra note 10, at $\S 3-116(2)$.

171. See id.

172. For discussion of the precursor of this provision in the Iowa statute, see Bonfield, supra note 150 , at $787-91,839$. Bonfield notes that this provision is "bristling with qualifications" and is "very narrowly drafted." Id. at 787.

173. The new Model Act provides that a rule adopted without substantial compliance with the procedural provisions of the act is invalid. 1981 MODEL ACT, supra note 10, at $\S 3-113(a)$. See Independent U.S. Tanker Owners Comm'n v. Lewis, 690 F.2d 908, 920-22 (D.C. Cir. 1982) (adjudication can stand despite reliance on invalidly adopted rule because result in adjudication not dictated; agency bound by procedures set forth in the imvalid rule); State v. Van Wie, 382 A.2d 372, 374-75 (N.H. 1978) (if breathalyzer manual had not been filed in "substantial complance" with state law, the drunk driving law would have been unenforceable). 
enable persons threatened by sanctions for violation of licensing or other regulatory laws to avoid enforcement.

d. Effect of the required rulemaking provisions. A broadened requirement of pre-adoption procedure will impose additional bureaucratic costs on agencies, discouraging the adoption of nonlegislative rules. ${ }^{174}$ The publication of fewer nonlegislative rules will result in poorer administration and less guidance to the public. Although a Comment to the new Model Act articulates this concern, ${ }^{175}$ it fails to explain how the Act is responsive to the problem.

The new Model Act does contain several provisions that may help counteract the negative effects of increased pre-adoption procedures. Section 2-104(3) requires an agency to "adopt rules, in addition to those otherwise required by this Act, enbodymg appropriate standards, principles, and procedural safeguards that the agency will apply to the law it administers." 176 Likewise, section 2-104(4) requires an agency to "adopt rules to supersede principles of law or policy lawfully declared by the agency as the basis for its decisions in particular cases." 177 To the extent these provisions are enforceable, an agency would no longer be free to bypass rulemaking techniques. Instead, as its "standards" or "principles" evolved through administration or adjudication, it would be compelled to express them in the forn of legislative or nonlegislative rules. ${ }^{178}$

Sections 2-104(3) and (4) may amehorate the negative effects of more stringent pre-adoption procedures. However, rulemaking is not required under either subsection until it is "feasible," and then only "to the extent practicable." 179 Courts are likely to defer to an agency deterinination that a "standard" or "principle" is still evolving, or that codification

174. See supra notes $114-31$ and accompanying text.

175. See 1981 MODEL ACr, supra note 10, at § 3-109 comment. The Comment reflects the personal views of Professor Bonfield, who drafted this portion of the 1981 Act and would have preferred no pre-adoption procedures for nonlegislative rules. Telephone conversation with Arthur Bonfield, Jnly 25, 1984.

176. 1981 MODEL ACr, supra note 10, at § 2-104(3). See Bonfield, State Law in the Teaching of Administrative Law, 61 TEX. L. REV. 95, 104-08 (1982).

177. 1981 MODEL ACr, supra note 10 , at $\$ 2-104(4)$.

178. The Commissioners poimt out that policymaking by rule has several advantages, including the "greater ease of public access to law embodied in widely disseminated published rules as compared to law embodied in unpublished orders which are only available in the agency's office for public inspection." Id. at § 2-104 comment. The Commissioners further acknowledge that "[o]nly by the enactment of a statutory provision of the type recommended here . . . can agencies be forced to codify in rules principles of law or policy . ... Without such a provision they will be free, in many situations, to make their most controversial pohicies on a case-by-case basis in adjudications ...."Id.

179. See id. at $\S \S 2-104(3)$ and (4). 
is inappropriate. ${ }^{180}$ Moreover, it is far from clear whether sufficient enforcement resources will be available. While the executive, legislative, and judicial branches struggle to enforce sections 2-104(3) and (4), ${ }^{181}$ the new requirements for adoption of nonlegislative rules will exert their substantial negative effects. How much inore effective sections 2-104(3) and (4) would have been if they were not accompanied by provisions requiring agencies to incur substantial costs in implementing them through adoption of nonlegislative rules.

\section{B. Congressional Proposals.}

Regulatory reform legislation was approved by the Judiciary Committees of the House and Senate during the 97th Congress. Both bills contained versions of the substantial impact test. Although the Senate bill passed unanimously, ${ }^{182}$ the House bill never came to a vote. Similar legislation was introduced in the 98 th Congress, ${ }^{183}$ but to date no substantial progress has been made.

The House bill, H.R. 746, required notice and coniment procedure if a nonlegislative rule "has general applicability and would have a substantial impact on substantive rights or obligations of persons outside the agency and otherwise has the effect of a substantive rule." 184 The House Judiciary Committee report clearly articulated the theoretical difference between legislative and noulegislative rules and observed that an agency should have the choice whether or not to inake use of its delegated power. ${ }^{185}$ The report pointed out, lowever, that noulegislative rules occasionally have a substantial practical impact on behavior even though they have no definitive legal effect. ${ }^{186}$ In sucl1 cases, the report observed, the public would value an opportumity to influence the content of the rule tlirough pre-adoption notice and comment procedure. ${ }^{187}$

180. Furthermore, neither section 2-104(3) or (4) clearly requires adoption of interpretive rules because interpretations might be neither "standards" nor "principles."

181. The new Model Act provides for agency self-review, review by the governor, and review through an administrative rules review committee of the legislature. See 1981 MODEL ACT, supra note 10 , at $\S \S 3-201$ to 204.

182. See S. 1080, 97th Cong., 1st Sess., 128 CoNG. REc. S2713 (daily ed. Mar. 24, 1982) (passage by a $94-0$ vote).

183. See S. 1080, 98th Cong., 1st Sess. (1983), H.R. 220, 98th Cong., 1st Sess. (1983), H.R. 2327 98th Cong., 1st Sess. (1983), H.R. 3939, 98th Cong., 1st Sess. (1983).

184. H.R. 746, 97th Cong., 2d Sess. $§ 201$ (1982), reprinted in House REPORT, supra note 101, at 8 (proposing a new 5 U.S.C. $\S 553(a)(3)$ ) (emphasis added).

185. See House RePORT, supra note 101, at 59 n.16, 61-62. The Senate bill was much less attentive to this distinction. See infra notes 197-200 and accompanying text.

186. See House RePORT, supra note 101, at 60.

187. Id. at $59-60$. 
Although the substantial impact test was widely accepted during the 1970 's, since that time an mcreasing number of courts have rejected it, in part because it furnishes so little guidance to agencies or reviewing courts. ${ }^{188}$ However, the House Judiciary Committee report on H.R. 746 tries valiantly to improve the predictability of the test. ${ }^{189}$

First, the report limits the scope of the test by a restrictive definition of the tern1 "general apphicability."190 Ordinarily, a rule has "general applicability" if it applies to an open-ended class of persons, rather than to one or a few named recipients. ${ }^{191}$ However, according to the Committee report, a rule is generally applicable only if it pertains to all or a majority of regulated parties-not to simgle individuals or products or to a defined class. ${ }^{192}$

This approach seems poorly considered. Regulations almost never impinge on every private sector entity regulated by an agency, or even on a majority of thein. Agencies such as the FTC, the EPA, or OSHA, for example, issue regulations that affect large numbers of businesses, but even their legislative regulations seldom involve a majority of businesses nationwide. Instead, both legislative and nonlegislative rules almost always mvolve subgroups, such as particular industries, groups within industries, particular products, or classes of beneficiaries. It is difficult to understand why the substantial impact test should apply only to those very few nonlegislative regulations that affect at least a majority of the parties that an agency regulates. Often, the rules that are the most questionable, and inost in need of public input, may be those that disadvan-

188. See supra notes $78-79,100-06$, and accompanying text.

189. The Committee emphasized that its substantial impact test would apply solely to nonlegislative rules. HOUSE REPORT, supra note 101, at 60 . Thus the Committee would apparently preserve the existing legal effect and definitiveness tests for distinguishing legislative and nonlegislative rules. Consequently, H.R. 746 would do nothing to clarify the characterization problem. See supra notes 39-107 and accompanying text.

190. See HOUSE REPORT, supra note 101, at 60-61 (rule must pertain "to all regulated parties or a majority thereof").

191. See generally Comment, supra note 31, at 364-72. See also AtroRney General's MANUAL ON THE APA, supra note 14, at 22-23. Some cases have equated "general applicability" with "substantial impact." See, e.g., Anderson v. Butz, 550 F.2d 459, 463 (9th Cir. 1977); Lewis v. Weinberger, 415 F. Supp. 652, 659 (D.N.M. 1976). However, if "general applicability" meant "substantial impact," the generality test in H.R. 746 would seem to be redundant.

192. HOUSE REPORT, supra note 101, at 60-61. This definition of "generality" goes well beyond what courts have required. When they addressed the issue of generality, courts found that "pervasiveness" of impact was sufficient. See, e.g., Pharmaceutical Mfrs. Ass'n v. Finch, 307 F. Supp. 858, 863 (D. Del. 1970) (impact on imdustry or miportant class of members or products of that industry).

The House Report stated that it specifically did not intend to require pre-adoption procedure for the adoption of IRS revenue rulings. See HouSE REPORT, supra note 101, at 62 . Although IRS rulings often have a significant adverse impact upon a large number of taxpayers, the exemption from pre-adoption procedure seems designed to prevent disruption of IRS operations. 
tage a defined subgroup within an industry while benefitting another, perhaps more influential, subgroup.

Second, the impact on persons outside the agency must be "substantial," defined as "palpable and significant," not "imcidental or trivial." 193 This definition may provide some guidance to agency staff members. But if members of the public choose to hitigate the validity of a nonlegislative rule adopted without notice and comment, a reviewing court will be hard pressed to conclude that the rule had only a "trivial" impact on them. The bill's definition of "substantial" fails to describe how agencies or courts should weigh the impact of a nonlegislative rule.

Finally, a nonlegislative rule must affect "substantive rights or obhgations" rather than procedural rights or mere interests. ${ }^{194}$ However, it is often difficult to distinguish substantive and procedural rights, ${ }^{195}$ and even more difficult to distmguish rights and "mere imterests."196 These concepts lack sufficiently firm content to guide either agencies or courts in deciding whether pre-adoption procedures are legally required.

The Senate's version of regnlatory reform legislation, S. 1080, required notice and comment where a nonlegislative or a procedural rule has general applicability and "substantially alters or creates rights or obligations of persons outside the agency."197 This provision reflects a fundamental misunderstanding of the difference between legislative and nonlegislative rules. Only a statute or a legislative rule, made under delegated authority, can "alter or create" a "right or obligation."198 Nevertheless, the Senate Judiciary Committee report makes clear that its test is intended to reach nonlegislative rules. ${ }^{199}$ Although it is somewhat mud-

193. HouSE REPORT, supra note 101, at 61 .

194. Id. The Judiciary Committee stated that this limitation would alter the judicial substantial impact test, but did not explain which cases it disapproved. Id.

195. Under the APA, procedural rules are exempt from notice and comment proceedings. 5 U.S.C. $\S 553$ (b)(A) (1982). However, rules that have a substantial impact on the rights or duties of persons outside the agency are not "procedural." See supra note 80 . Thus, the Judiciary Committee's substance-procedure test is circular. A rule has a substantial impact only if it affects substance rather than procedure; but whether it affects substance rather than procedure depends on whether it has a substantial impact!

196. See HouSE REPORT, supra note 101, at 61 ("courts should identify and distinguish substantive rights or obligations from procedural rights, or from mere interests, im accordance with existing law").

197. S. 1080, 97th Cong., 1st Sess. $§ 3,128$ Cong. REc. S2713, S2713 (daily ed. Mar. 24, 1982).

198. See, e.g., Associated Dry Goods Corp. v. EEOC, 720 F.2d 804, 812 (4th Cir. 1983) (EEOC lacks legislative rulemaking power, so its rules cannot have impact on anyone's rights); Noel v. Chapman, 508 F.2d 1023, 1030 (2d Cir. 1975) (INS rules did not mupose an obligation), cert. denied, 423 U.S. 824 (1976). See also Asmiow, supra note 7, at 547-51 (comparing "substantial mipact" standards focused on legal effect with those focused on practical effeet).

199. SENATE REPORT, supra note 39, at 110-14.

Some of the decisions cited by the Senate report did observe that nonlegislative rules affeeted substantive rights and obligations. See, e.g., Lewis-Mota v. Secretary of Labor, 469 F.2d 478, 481-82 
dled, the report emphatically approves of the judicial substantial impact test and criticizes the prevailing legal effect test. ${ }^{200}$

The Senate Report is even less helpful than the House Report in supplying guidance to agencies or courts. According to the Senate Report, if a rule does not have general apphicability, has only an insubstantial impact, or affects only expectations, it would remain exempt from notice and coinment procedures. ${ }^{201}$ Although the report does little to define these nebulous generalities, it dispenses generous quantities of gratuitous advice. For example, it criticizes the use of nonlegislative rules to modify existing understandings of the requirements of the statute or regulation, even though those understandings might have themselves arisen from nonlegislative rules. ${ }^{202}$ The Senate's bill would effectively abolish the nonlegislative rule exemption. Taken together, its standards and admointions are so broad that they appear to sweep all nonlegislative rules of any consequence into notice and comment procedures. ${ }^{203}$

The legislative substantial impact test proposed by either bill would result in great confusion and would vastly increase the amount of litigation about the validity of controversial rules. In effect, therefore, it would amount to a de facto repeal of the nonlegislative rule exeinption. As we have seen, the costs of such a repeal would far outweigh the benefits. ${ }^{204}$ Thus, when Congress returns to the subject of regulatory reform, it

(2d Cir. 1972), cited in SeNATE RePoRT, supra note 39, at 113. However, this is true only in the sense that the rules affected the behavior of private parties or agency officials, and thus had an impact on the manner in which the public enjoyed its rights or discharged its obligations.

200. SENATE REPORT, supra note 39, at $111,113$.

201. See id. at 111-14. Like the House version, the Senate bill would require notice and coinment only if a rule had "general applicability." However, the House Report defined this term so narrowly that, taken literally, very few rules would have general applicability. See supra notes 190 92 and accompanying text. There is no such caution in the Senate Report.

202. See SENATE REPORT, supra note 39, at 113 (an agency statement changing existing understanding of the requirement of a statute would be subject to notice and comment). Similarly, it declares that only legislative rules shonld be used to fill gaps in existing regulations, to indicate relevant factors in future rulemaking, to change existing licensing practices, or to supply guidance in nuclear plant construction. Id. at 111-12. Yet each of these functions would often be discharged by nonlegislative rules-often by agencies with no legislative rulemaking power at all.

203. The Senate Report accurately summarized the effect of its proposals: "Generally there are few rules which automatically can be decmed exempt from section 553 rulemaking under this provision merely because they belong to a class of rules which normally are exempt. It is conceivable that a rule, of a type usually considered interpretative, may in certain circunstances have the kind of substantial impact on rights or obligations which remove it from the ambit of this modified exemption for interpretive rules." Id. at 113. Thus, the Report observed that IRS revenue rulings would ordinarily be exempt froin notice and comment rulemaking, but promptly criticized a case that refused to require notice and comment before adoption of a ruling. See id. at 112-13 (criticizing National Restaurant Ass'n v. Simon, 411 F. Supp. 993, 999 (D.D.C. 1976) (revenue rulings are interpretive rules). The House Report approved the National Restaurant case. See HousE REPORT, supra note 101, at 62.

204. See supra notes 107-30 and accompanying text. 
should abandon efforts to legislate the substantial impact test and should seek a much more cautious approach to the problem of public participation in the adoption of nonlegislative rules. The next section of this article suggests one such approach.

\section{Post-adoption Notice and Comment: Administrative Conference Recommendation 76-5.}

In 1976, the Administrative Conference of the Umited States (ACUS) adopted Recommendation 76-5, a modest reform proposal addressed to agencies rather than to Congress or the courts. ${ }^{205}$ Recommendation 76-5 suggested that voluntary notice and comment procedures be employed when an agency anticipates that a nonlegislative rule imight have a substantial impact on the public. ${ }^{206}$ This voluntary approacli ecloes admonitions in the legislative history of the APA. ${ }^{207}$

In the case of generally applicable nonlegislative rules that lack a substantial impact, ACUS recommended that an agency nivite niembers of the public to subrimt comments for a thirty day period after the rule is adopted. ${ }^{208}$ The agency would be required to respond to the comments within a sixty day period. ${ }^{209}$ This recommendation for inandatory postadoption comment is suitable for niclusion in regulatory reform legislation.

The post-adoption procedure has a number of advantages over both present law and other regulatory proposals. First, it would not delay the effective date of a rule. Because most nonlegislative rules are either trivial or clearly valid, they will elicit no comments and thus require no administrative response. Indeed, post-adoption comment does not differ significantly from the existing provision in section 553(e) of the APA, which allows interested persons to petition for the amendment or repeal

205. 1 C.F.R. $\$ 305.76-5$ (1984). See also Asimow, supra note 7, at 573-84. This Recommendation influenced the House Judiciary Committee's decision to adopt the substantial impact test. See House REPORT, supra note 101, at 62 . Consistent with Recommendation $76-5$, ACUS has also recommended post-adoption comment in the case of rules adopted under the good canse exemption. 1 C.F.R. $\S 305.83-2$ (1984).

206. 1 C.F.R. $\$ 305.76-5$ (1984).

207. The APA legislative history indicates that Congress wanted agencies to use pre-adoption procedures when adopting nonlegislative rules in cases where it would be helpful to them or to the public. See APA Legislative History, supra note 94, at 187. The courts have also admonished agencies to utilize pre-adoption procedures, and agencies quite frequently do so. See Guardian Fed. Sav. \& Loan Ass'n v. FSLIC, 589 F.2d 658, 669 (D.C. Cir. 1978) (recommending but not requiring the use of notice and comment); Asimow, supra note 7, at 524-28, 542, 559-60.

208. 1 C.F.R. $\S 305.76-5$ (1984).

209. Id. This procedure could be omitted if an agency found it would serve no public purpose or that it would be so burdensome as to outweigh any foreseeable gain. $I d$. 
of a rule. ${ }^{210}$ As a result, post-adoption procedure should not significantly deter agencies from adopting nonlegislative rules.

Second, a requirement of post-adoption procedure would in practice lead agencies to provide pre-adoption procedures for important rules that are expected to provoke substantial comment. In such situations, the staff inay well prefer the usual and familiar pre-adoption routine instead of inandatory reconsideration of an already-adopted rule. Consequently, advance public participation in nonlegislative ruleınaking should increase substantially.

Third, post-adoption comment periods can be quite effective. The comments will, im many cases, identify shortcomings in the rule that can be swiftly repaired.211 When members of the public know that their input must be read, considered, and commented upon, they will be more likely to take the trouble to make comments.

Fourth, a record consisting of public comments and agency responses wonld be imvaluable to a court engaged in pre-enforcement judicial review of the vahidity of a nonlegislative rule. ${ }^{212}$ The absence of a record makes review more difficnlt and encourages courts to hold the rules unripe for review. ${ }^{213}$ The availability of a more detailed record wonld assist a court im determining, for example, whetlier a nonlegislative rule is reasonable or arbitrary or whether it is consistent witl the underlying statute.

Finally, post-adoption comment imvites the public to share in the process of making all nonlegislative rules. In fact, because a rule that lias been adopted is more visible tlian a proposed rule, it might attract even wider attention and comment than a pre-adoption invitation. Greater public involvennent should enhance the legitimacy of the rules. At the same time, post-adoption procedure would not, in the vast inajority of cases, delay the adoption of rules nor should it discourage agencies from adopting thein.

210. See 5 U.S.C. $\$ 553(\mathrm{e})$ (1982).

211. See, e.g., Levesque v. Block, 723 F.2d 175, 188 (1st Cir. 1983) (Secretary changed rules in response to post-adoption comments).

212. Moreover, a person who seeks pre-enforcement review might well be required first to exhaust the post-adoption procedure remedy. Such a requirement would be an additional incentive for affected persons to take part in the comment process, would improve the record on review, and would minimize the number of obstructive judicial challenges to probably valid rules.

213. See, e.g., American Fed'n of Gov't Employees v. O'Connor, 747 F.2d 748, 752-57 (D.C. Cir. 1984); Tennessee Gas Pipeline Co. v. FERC, 736 F.2d 747, 750 (D.C. Cir. 1984); Pacific Gas \& Elec. Co. v. FPC, 506 F.2d 33, 49 (D.C. Cir. 1974) (general statements of policy are not subject to judicial review if there is no immediate and significant impact). However, a number of nonlegislativc rules have been subjected to pre-enforcement review. See, e.g., National Automatic Laundry and Cleaning Council v. Schultz, 443 F.2d 689, $691-700$ (D.C. Cir. 1971). See Asimow, supra note 7, at 567-69. 
Of course, there is one obvious disadvantage to post-adoption procedure-comments made after a rule is adopted may be less effective in influencing the rulemaking process. The thinking of the staff undoubtedly rigidifies after an agency has adopted and published a rule in final form. At that point, both the staff and the agency heads may be less open to alternatives, and may react defensively to critical comments. For that reason, members of the public might be less willing to take the trouble to prepare comments. ${ }^{214}$

Several recent cases suggest that post-effective comment inay indeed be a ineaningful process. These decisions address the issue of whether an invitation to submit comments after a rule is adopted can validly substitute for pre-adoption notice and comment. While earlier cases disapproved this expedient, ${ }^{215}$ the trend inay be reversing. For example, in Levesque v. Block, ${ }^{216}$ plaintiffs cliallenged rules adopted by the Departinent of Agriculture as invalid because they were adopted without prior notice and comment. ${ }^{217}$ The Department claimed that the rules were exempt from notice and comment requirements under both the interpretive and good cause exemptions. ${ }^{218}$ The First Circuit rejected the agency's claims, but refused to invalidate the rules because the agency liad invited and received post-adoption comments. ${ }^{219}$ In response to the comments, the Departinent of Agriculture made a number of changes in the rules, and gave reasonable replies to those suggestions that it declined to follow. ${ }^{220}$ Under those circumstances, the court granted relief only to persons with clainis arising between the invalid initial promulgation of the rules and the effective date of the rule as re-promulgated after the comment period. ${ }^{221}$ Levesque and other recent decisions ${ }^{222}$ indicate that

214. Comments on already-adopted rules could not be ignored. ACUS Recommendation 76-5 requires the staff to comment on the submissions. 1 C.F.R. $\S 305.76-5$ (1984). This assures at least a perfunctory response to public comments.

215. See, eg., New Jersey v. EPA, 626 F.2d 1038, 1049-50 (D.C. Cir. 1980); Standard Oil Co. v. Department of Energy, 596 F.2d 1029, 1061-62 (Temp. Emer. Ct. App. 1979).

216. 723 F.2d 175 (1st Cir. 1983).

217. Id. at 178-79.

218. Id. at 179.

219. Id. at 179-89. The Secretary received 130 comments on the rules. Id. at 188.

220. Id. at 188-89.

221. Id. at 189.

222. See Petry v. Block, 737 F.2d 1193, 1203 (D.C. Cir. 1984) (Department of Agriculture's open-minded treatment of post-promulgation comments overcame any presumption against a late comment period); Western Oil \& Gas Ass'n v. EPA, 633 F.2d 803, 813 (9th Cir. 1980) (rule invalidly adopted in reliance on good cause exemption remains in effect pending new cycle of notice and comment). See also Note, Remedies for Noncompliance with Section 553 of the Administrative Procedure Act: A Critical Evaluation of United States Steel and Western Oil \& Gas, 1982 Duke L.J. 461, 476-82. 
a post-effective comment period need not be a sham and can be a reasonably satisfactory solution to a difficult problem.

Some opponents of this proposal have complained that it will increase staff workload, ${ }^{223}$ because the staff will have to respond to comments, and perhaps reconsider rules, within a defined time frame. ${ }^{224}$ Not surprisingly, the reconsideration of nonlegislative rules is rarely a high priority task. However, it is unlikely that anyone will comment on the vast majority of all nonlegislative rules. Moreover, the public can create the same burden under existing law by petitioning for repeal or amendment of any rule. ${ }^{225}$

\section{E. Regulatory Reform: Substance and Procedure.}

The history of American administrative law demonstrates a steady trend toward judicialization of process, administrative openness, and increased judicial review. That history also suggests a persistent mixture of procedural and substantive concerns. ${ }^{226}$ Many tinnes, the advocates of new procedures are amimated not so much by procedural concerns but by hostility toward the substantive programs that the agencies pursue.227

Sometimes opponents of a new substantive program successfully negotiate for statutory provision of detailed procedures that, in practice, render the regulatory program cumbersome and unworkable. In other cases, opponents of existmg programs who lack the political muscle to achieve deregulation or changes in the substantive provisions of a statute will concentrate instead on procedural reforms. By making it difficult and costly for an agency to adopt rules or conduct adjudications, these reformers hope that the agency will adopt fewer rules and adjudicate fewer cases or that new procedures will slant whatever regulatory out-

The Senate bill would have required post-effective comments for rules adopted under the good cause exemption. S. 1080, 97th Cong., 1st Sess., (1982) (proposed amendment to 5 U.S.C. $\S 553(\mathrm{~b})(2)(\mathrm{C})$ ); see Jordan, supra note 81 , at 169-70.

223. See letters to Robert Anthony, Chairman of the Administrative Conference, from the Federal Home Loan Bank Board (March 8, 1977), the Secretary of Labor (Sept. 8, 1976), and the ICC (Aug. 20, 1976), all on file with the author.

224. If the post-adoption procedure were embodied in the APA, the 60-day response period should be made more flexible to take account of agency workload or other priorities. Perhaps the agency should be required only to respond within a reasonable time.

225. See 5 U.S.C. $\$ 553(\mathrm{e})(1982)$.

226. See Davis, Regulatory Reform and Congressional Control of Regulation, 17 NEW ENG. L. REV. 1199, 1199-1200 (1982) (noting that a schism exists between regulatory reformers who favor regulation generally but nevertheless see the need for improvements in regulatory procedures, and those regulatory reformers who are simply proponents of deregulation).

227. See Verkuil, The Emerging Concept of Administrative Procedure, 78 Colum. L. REV. 258, 268-78 (1978) (discussing the connection between substantive opposition to regulation and procedural reforms during the 1930's). 
puts the agency manages to produce. ${ }^{228}$ Sometimes reformers seem intent on laying as many snares as possible in the path of an agency in order to mcrease the likelihood of a mistake and judicial invalidation on procedural grounds. ${ }^{229}$ It seems evident to the author that inany current advocates of regulatory reform advance procedural proposals as a surrogate for substantive deregulation that they lack the pohitical power to achieve.

This article is a plea to regulatory reformers to treat legislative and noulegislative rules separately. Many reasons why one might favor reforms of or controls over the legislative rulemaking process are not at all applicable to nonlegislative rules. Even if one seeks to inake rulemaking inore difficult so that agencies will do less of it, it does not follow that one should try to make nonlegislative rulemaking more difficult.

Given that a scheme of regulation exists, and given that an agency has adopted the legislative rules necessary to set it in inotion, it serves the interests of everyone-the agency and its staff, the regulated parties, the public, stauncli proponents and opponents of the regulatory scheine, seekers of efficiency, seekers of fairness-that the agency provide guidance in the form of generally apphicable imterpretive rules and pohicy statements. Costly and cumbersoine procedures that would enhance the ability of a few inembers of the public to influence the content of a few important noulegislative rules seriously disserve all these interests because they will necessarily decrease the flow of nonlegislative rules.

\section{CONCLUSION}

Noulegislative rules have puzzled students of the administrative process for many decades. They are concerned about both the timing and the scope of judicial review of such rules, about the extent to whicl they can be retroactive or prospective and whether they bind the agency, about the effect of their nonpublication, and about low legislative and nonlegislative rules can be distinguished from one another. Most of all,

228. See Magat \& Schroeder, Administrative Process Reform in a Discretionary Age: The Role of Social Consequences, 1984 DukE L.J. 301 (impact on outcomes of procedural reforms); Chairman's Message, 35 AD. L. REv. iii, v (Winter 1983) (interest in procedural reforms is motivated by desire to influence substantive rules); Davis, supra note 226, at 1201-04 (overregulation of the economy requires better managenent of agencies); Scalia, Vermont Yankee: The APA, the D.C. Circuit, and the Supreme Court, 1978 Sur. Cr. REV. 345, 40409 (rulemaking procedural reforms often are attempts to limit or alter agency power); $c f$. Scalia, Regulatory Reform: The Game Has Changed, 5 REG. Jan.-Feb. 1981, at 13, 13 (noting that procedural reforms make substantive deregulation difficult).

229. See, e.g., Rago, Rulemaking under the Model State APA: An Opportunity Missed, 34 AD. L. REv. 445, 446 (1982) (arguing that the Model State APA does not provide adequate safeguards against arbitrary agency actions). 
observers sharply disagree about whether any form of public participation should be required in connection with the adoption of the rules and, if so, when it should be accorded and what form it should take.

This article has criticized all of the different approaches to the problem of public participation in nonlegislative rulemaking. The shortcomings of the new Model Act and of the federal regulatory reform proposals are inanifest, but the status quo also leaves much to be desired. At least, under the legal effect and definitiveness tests, an agency can be relatively but not absolutely certain that a court will defer to a carefully prepared cliaracterization. Yet when rules have a substantial impact on members of the public, pre-adoption notice and comment procedure would serve the imterests of improved rules as well as administrative responsiveness and effectiveness. Sucl participation is assured by a judicial or legislative substantial impact test, but that test fails to give sufficient guidance to agencies or reviewing courts. Even if a nonlegislative rule lacks substantial impact on the lives or fortunes of those affected by it, the rule would in inany cases benefit from the input of interested inembers of the public. Yet to open all nonlegislative rules to advance public participation would lhave a devastatingly negative effect on the administrative process.

On the whole, it seemed to the Administrative Conference and it seems to this writer that the inodest benefit to the public from a postadoption comment system would outweigli the modest additional costs that it would impose on agency staffs. Reformers should seriously question the mucli costlier requirements imposed by the 1981 Model Act and the proposals to write some form of impact test into the federal APA. These "reforms" would have perverse effects and would not advance the cause of regulatory reform. 